Historic, Archive Document

Do not assume content reflects current scientific knowledge, policies, or practices. 



\section{CONTAINER PROCUREMENT BY COOPERATIVE FRESH FRUIT AND VEGETABLE PACKERS}

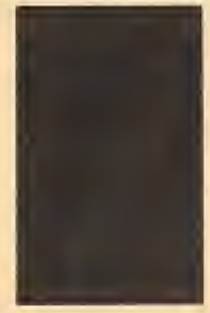

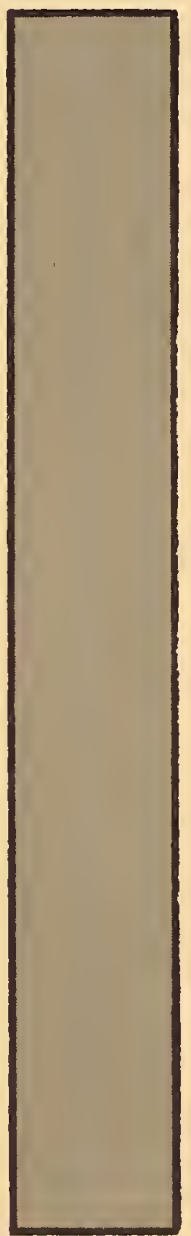

FCS Research Report 3
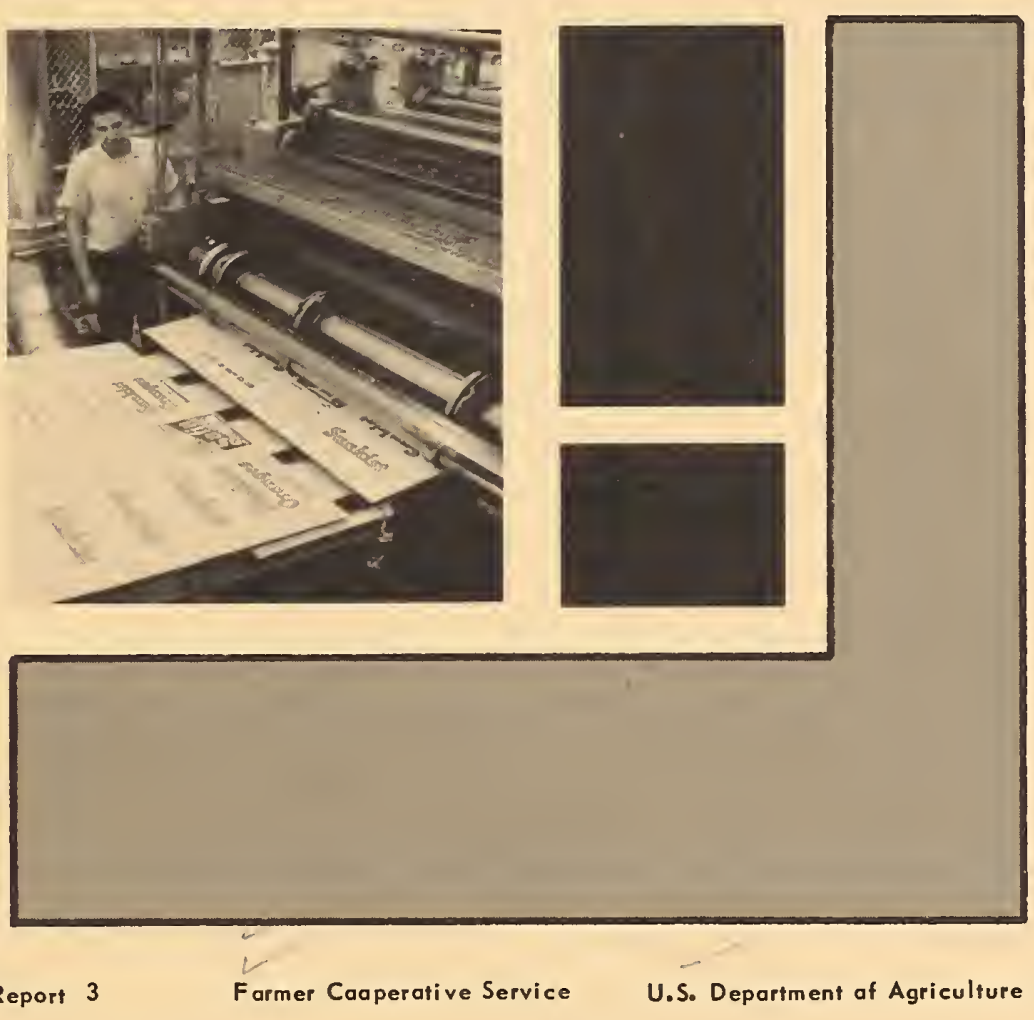


\section{FARMER COOPERATIVE SERVICE U.S. DEPARTMENT OF AGRICULTURE WASHINGTON, D.C. 20250}

Farmer Cooperative Service conducts research; advises directly with cooperative leaders and others; promotes cooperative organization and development through other Federal and State agencies; and publishes results of its research, issues News for Farmer Cooperatives, and other education material.

This work is aimed (1) to help farmers get better prices for their products and reduce operating expenses, (2) to help rural and small-town residents use cooperatives to develop rural resources, (3) to help these cooperatives expand their services and operate more efficiently, and (4) to help all Americans understand the work of these cooperatives.

This study was made under contract by Agri Research, Inc., Manhattan, Kans. Dr. Raymond J. Seltzer, Donald J. Wissman, and others did the fieldwork and prepared a detailed report of findings.

This publication on procuring containers for fresh fruit and vegetables complements a similar one recently issued on processed fruit and vegetables. This was FCS General Report 146, "Cooperative Procurement of Containers for Fruit and Vegetable Processing," November 1967.

Use of firm names does not constitute endorsement or imply discrimination against other firms. 


\section{CONTENTS}

Page

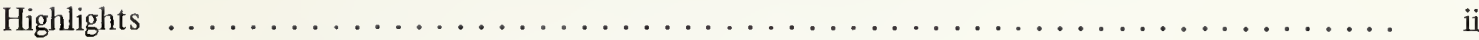

Purpose, Scope, and Method of Study $\ldots \ldots \ldots \ldots \ldots \ldots \ldots \ldots \ldots \ldots \ldots$

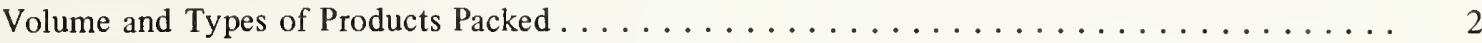

Containers and Packaging Supplies Purchased . . . . . . . . . . . . . . . . 5

Annual container costs . . . . . . . . . . . . . . . . . . 5

Container costs as a percent of total packing costs . . . . . . . . . . . . 6

Container costs as related to sales of fresh products $\ldots \ldots \ldots \ldots \ldots \ldots \ldots$

Types of Containers Handled and Trends in Container Use . . . . . . . . . . . . . 8

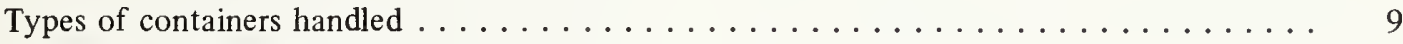

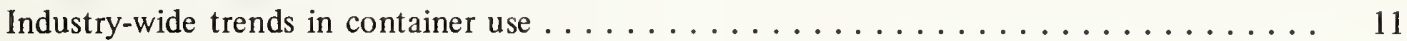

Existing Procurement Practices . . . . . . . . . . . . . . . . . . . 12

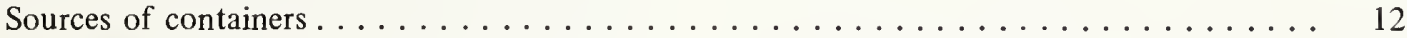

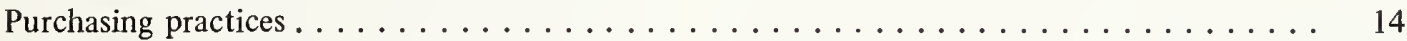

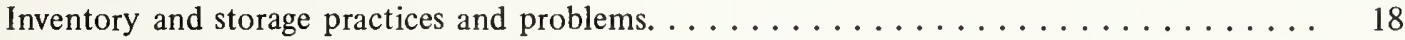

Transportation methods . . . . . . . . . . . . . . . . . . . . . . . 19

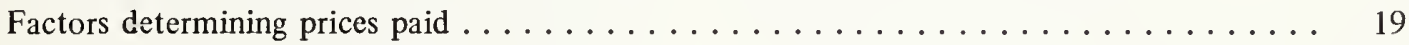

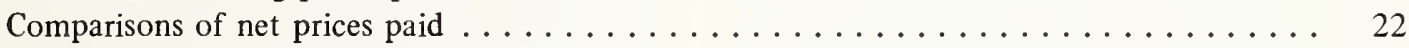

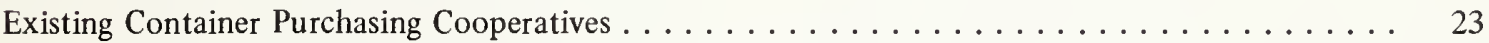

Exchange Supply and Service Cooperative, Tampa, Fla . . . . . . . . . . . . 23

Glades Brokerage Company, Pahokee, Fla. . . . . . . . . . . . . . . 24

Northwest Wholesale Inc., Wenatchee, Wash. . . . . . . . . . . . . . . . 24

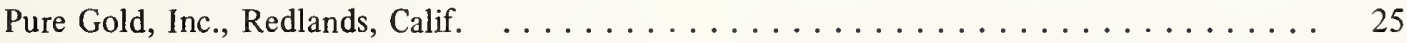

Michigan Certified Farm Markets, Lansing, Mich. . . . . . . . . . . . . 26

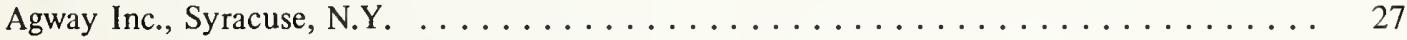

Existing Container Manufacturing and Fabricating Cooperatives ............. 27

Highland Crate Cooperative, Jacksonville, Fla. . . . . . . . . . . . . . . 27

Fruit Growers Supply Company, Los Angeles, Calif . . . . . . . . . . . . . . . . . . 29

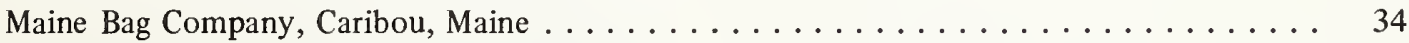

Further Opportunities for Cooperative Procurement of Containers . . . . . . . . . . 38

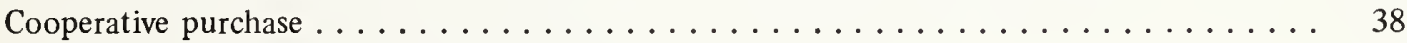

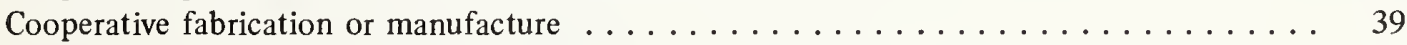

Regional analysis . . . . . . . . . . . . . . . . . . . . . . . 39

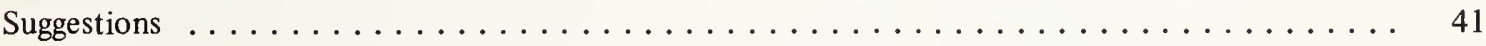

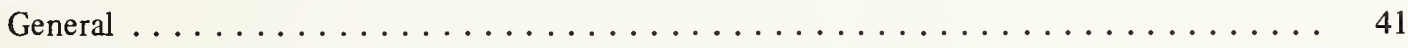

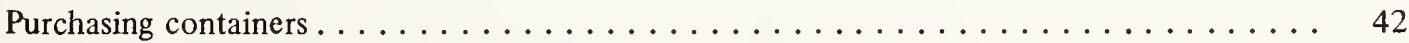

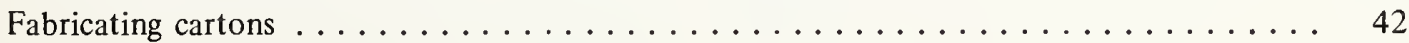

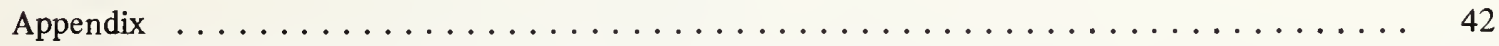

Uniform Members' Contract of Highland Crate Cooperative . . . . . . . . . . . . . . 42

Tables . . . . . . . . . . . . . . . . . . . . . . . . . . . . 44 



\section{HIGHLIGHTS}

Many cooperative packers of fresh fruit and vegetables procure their containers and other packaging materials on a cooperative basis at substantial savings. Possibilities exist for others to obtain their container needs through joint action at savings averaging perhaps 10 percent.

Savings up to 10 percent may be realized from volume discounts, brokerage allowances, or negotiated prices for consolidated purchases. Five percent might be saved in fabricating and printing paperboard containers, but a more important advantage may be the assurance of a supply of high-quality containers. Savings of 10 to 14 percent may be available from the cooperative manufacture of burlap and paper bags, based on the experience of the only cooperative bag plant in the country. And although the use of wooden containers has been declining, one cooperative has averaged net savings of about 14 percent from manufacturing crates for citrus since 1945.

Estimates indicate that all cooperatives buy $\$ 63$ million worth of containers and other packing supplies a year for packing some $\$ 600$ million worth of fresh fruit and vegetables. If savings of 10 percent could be made through cooperative procurement of half of this volume, the potential savings for growermembers would be over $\$ 3$ million a year.

Information from 251 marketing cooperatives indicated that containers and other packing supplies were the largest single packing cost, exclusive of the raw product. Purchases of these items averaged $\$ 97,300$ per association and represented 43 percent of total packing costs for fruit and 39 percent for vegetables. Such costs were equal to 10.4 percent of the sales value of the fresh products.

Cooperative fruit and vegetable packers in California, Florida, Maine, and Washington obtained about 56 percent of their containers and packaging supplies from container supply cooperatives or supply divisions of regional marketing associations, and 42 percent direct from manufacturers. In other States, where there are few cooperative sources, marketing co-ops bought almost 80 percent of their containers from manufacturers and 15 percent from local private suppliers.

The main reason for using cooperative source was savings in cost-reported by 74 percent. Service was listed by 16 percent. Another group considered slow or poor service as a disadvantage of this source, and others did not want to be entirely dependent upon one source.

The major reasons given for purchasing containers from manufacturers were lower prices, good service, and quality. The principal disadvantage others mentioned was slow or poor service.

Thirty-nine percent of the cooperatives contacted purchased containers only for their own use; 23 percent bought them only for the use of growershipper members; and 38 percent bought containers for both types of uses. Purchase for resale to members was most common among vegetable growers where field packing was the general practice. None of the cooperatives made joint purchases with nearby packers.

Most co-ops purchased containers throughout the packing season, as deliveries could be obtained on short notice-from 1 day to 2 weeks. Their beginning and ending inventories were less than 10 percent of annual purchases. Three-fourths of the group used less than 5,000 square feet of storage space for containers.

Over 40 percent of the associations bought containers at negotiated prices, with competitive bidding based on quality and specifications of containers. Service, delivery dates, and quality also were considered.

Trade or quantity discounts were available to about 60 percent of the reporting cooperatives. Straight quantity discounts of 5 percent or carload or 
truckload lots were most common. When cooperatives resold containers to members and handled the order and billing, a 5-percent brokerage allowance was commonly available. In some cases, combinations of quantity discounts and brokerage allowances resulted in savings of 10 percent or more. One group had warehouse or storage allowances available at the rate of 0.65 percent per month for a maximum of 6 months. Ninety percent stated that discounts of 1 or 2 percent were available for prompt payment-within 10 days after billing.

About 86 percent of the container items were moved by truck and 14 percent by rail. Most shipments were in truckload lots and priced on a "delivered" basis.

Data obtained from the associations on net costs of major types of containers, after taking into account initial prices paid, discounts, brokerages, and patronage refunds, indicated the following savings through cooperative procurement; 4.4 percent on paperboard cartons for citrus in California; 7.3 percent on peperboard cartons and 8.5 to 16.9 percent on wirebound wooden boxes for citrus in Florida; 6.5 to 9.5 percent for cartons, 16 to 22 percent on wooden lug boxes, and 5 to 9 percent on polyethylene items for deciduous fruits in Washington; 4.6 percent on wooden crates for vegetables in Florida; and 11 to 14 percent on bags for potatoes in Maine.

Greatest opportunities for cooperative purchase or manufacture of containers appear to exist for a department within or for an affiliate of several co-ops, a large regional marketing cooperative. Regional cooperatives handling farm production supplies could purchase or fabricate containers, but most seem to have little interest in expanding into this type of service.

Most opportunities exist in cooperative purchasing on a brokerage basis. This can be undertaken with little staff, capital, and facility requirements.
Cooperative procurement of containers and packaging materials is well established in the citrus industry in California and Florida; in the deciduous fruit industry in California, Oregon, and Washington; and in the potato industry in Maine. Further opportunities appear feasible for the following areas and crops: (1) California-purchasing containers for fresh vegetables, essentially lettuce and artichokes, and for specialty crops such as figs, grapes, and strawberries; (2) Washington and Oregon-purchase of containers for specialized fruits and berries; (3) Floridafabrication of cartons for citrus, and purchase of containers for winter tomatoes; (4) Northeastern States-purchase of containers for mushrooms in Pennsylvania, vegetables in New Jersey, and fruits and vegetables in New York and other areas; (5) Michigan-purchase of containers for red cherries and vegetables; and (6) other States-purchase of containers for hothouse vegetables in Ohio, strawberries in Louisiana, citrus and vegetables in Texas, potatoes in Minnesota and the Dakotas, and perhaps fruit and vegetables in Arizona and Hawaii.

A cooperative container purchasing service should benefit co-ops or growers who need either a wide variety of containers or standardized containers. A brokerage cooperative could bargain for a diversified group of containers and provide a central office through which packers could order the variety of containers and packaging materials they require. Where only a few standard types of containers are required, a container-purchasing cooperative might effectively bargain with major manufacturers for a large volume of containers, or contract for the manufacture or fabrication of the major container types.

Possibilities for cooperative fabrication or manufacture of containers are limited to areas where a large volume of a few types of standard containers are required. Fabrication of containers rather than complete manufacture of materials seems most practical for present-day cooperatives. 


\section{CONTAINER PROCUREMENT BY COOPERATIVE FRESH FRUIT AND VEGETABLE PACKERS}

\section{By J. Warren Mather,}

\section{Director}

Farm Supplies Division

Several hundred cooperatives pack and market a wide variety of fresh fruits and vegetables each year. For these operations, they purchase a substantial quantity of containers and packaging supplies for their own use, and some also buy quantities for member-growers who pack and ship their own products. These associations require a variety of types and sizes of such items as paperboard cartons; wooden boxes, crates, baskets, and the like; burlap, cotton, and plastic bags; and wraps, fillers, liners, and labels.

Expenditures for these supplies often represent more than a third of total packing costs, and equal 10 percent or more of the sales value of the products marketed.

Because many marketing cooperatives are small, they buy containers and packaging supplies in quan- tities too small to obtain the most favorable prices or quantity discounts available.

To overcome this problem, five groups of local cooperatives have formed specialized container cooperatives to purchase or fabricate their container needs. For a number of years, one each has been operating in Washington and California, and three have served local marketing cooperatives and growershippers in Florida. Two of the container cooperatives have arrangements with paperboard container companies, and one manufactures wooden boxes. In addition, a few of the larger marketing cooperatives in other areas have established container supply departments to obtain their requirements.

A recent study of the procurement of containers by cooperative processors of fruit and vegetables showed worthwhile savings from cooperative purchasing various containers and manufacturing metal cans (see reference inside cover). If substantial savings could be made through more cooperative purchasing or fabrication this would help producers of fresh products reduce costs and increase net incomes.

\section{PURPOSE, SCOPE, AND METHOD OF STUDY}

The specific objectives of this project were to:

1. Analyze and evaluate the present system that marketing cooperatives use in purchasing and manufacturing containers and packaging supplies for fresh fruit and vegetables; and

2. Determine possible methods of effecting savings or improving services in the procurement of such containers and packaging supplies.
The study covered the United States, but special attention was devoted to the major fruit and vegetable production areas: Concentrated areas in Florida, California, and the Pacific Northwest, studied in 1964; and Northeastern and North Central States, studied in 1965.

Data were obtained from 251 mail questionnaires and personal interviews. A list of over 600 cooperatives reported to be marketing fresh fruit and 
vegetables was prepared. It was checked and updated by representatives of State Cooperative Councils, State Extension Services, Agricultural Experiment Stations, and others in the various States.

Personal interviews were conducted with 73 marketing cooperatives representative of the most concentrated areas of fruit and vegetable productionCalifornia, Washington, Florida, Ohio, Michigan, New Jersey, New York, Pennsylvania, and Maine (fig. 1 and appendix table A-1). Thirty-six of these associations packed only fruits, 27 packed only vegetables (except potatoes), 7 packed only potatoes, and 3 packed both fruits and vegetables. In addition, representatives of 6 cooperative container supply cooperatives, three general farm supply cooperatives, and three container manufacturers were interviewed.
Questionnaires were mailed to all of the remaining cooperatives reported to be marketing fresh fruits and vegetables. A total of 571 were mailed, and two letters followed to increase returns. ${ }^{1}$ Replies were received from 332 cooperatives, or 58 percent of the total. Of the replies, however, only 178 or 31 percent were usable. Some were no longer in business, some did not pack fresh products because they are selling and bargaining associations only, some did not buy containers, and a few did not provide complete information.

Of the 178 cooperatives providing usable data, 110 packed fruit only, 52 packed vegetables only, and 16 packed both (fig. 2).

\section{VOLUME AND TYPES OF PRODUCTS PACKED}

Many cooperatives and independent marketing firms and even more individual grower-shippers pack fresh fruit and vegetables. Because of the variety of products sold and the variety in size of packs, physical measures of volume sold vary widely. In addition, the volume that co-op vegetable packers report is not entirely representative of growermembers' sales, since they field-pack many products for direct shipment and do not sell all their products through the marketing cooperatives.

The 251 fruit and vegetable marketing co-ops in this study reported sales of $\$ 232$ million, or an

\footnotetext{
${ }^{1}$ In a recent study, 423 co-ops whose main business was marketing fresh fruits and vegetables and 59 whose main business was processing such products reported data on their 1964 operations. Seven associations marketing fresh products were federations of local cooperatives. See "Organization and Competition in the Fruit and Vegetable Industry," Natl. Comn. on Food Mktg. Tech. Study No. 4, pp. 111-132 and 255-272, June 1966.

FCS statistics showed 577 predominately fruit and vegetable cooperatives and 15 other types handling such products in the 1964-65. See Statistics of Farmer Cooperatives, 1964-65, FCS Gen. Rpt. 143.

The 95 associations not reporting in the Commission study were believed to be small, with some marketing fresh products and others marketing processed products.
}

average of $\$ 924,300$ in 1964 . This was less than half, however, of the sales reported to the National Commission on Food Marketing by 418 cooperatives (including two federations of cooperatives) that were primarily marketing fresh products in 1964-65. Their volume totaled $\$ 533$ million-an average of $\$ 1,275$ million per association.

Since it appears that some cooperatives did not report data for either study, we estimate that cooperatives marketed around $\$ 600$ million worth of fresh products in 1964-65.2 This excludes bargaining associations who negotiated for prices of members' products.

\footnotetext{
${ }^{2}$ Co-ops reporting volume to FCS in 1964-65 had gross sales of fruit and vegetables of $\$ 1.63$ billion and net sales (after excluding business between cooperatives) of $\$ 1.23$ billion. The data were not reported separately for fresh and processed products. Of these sales, about $\$ 110$ million represented the value of products negotiated for by bargaining associations. The remaining net sales of $\$ 1.13$ billion are close to the combined $\$ 1.15$ billion worth of fresh and processed products shown in the report of the National Commission on Food Marketing, but less than the combined total of $\$ 1.325$ billion of fresh and processed sales estimated in this report and in FCS Gen. Rpt. 146, dealing with containers for processed products. The variation may be due to some intercooperative sales in the latter reports.
} 


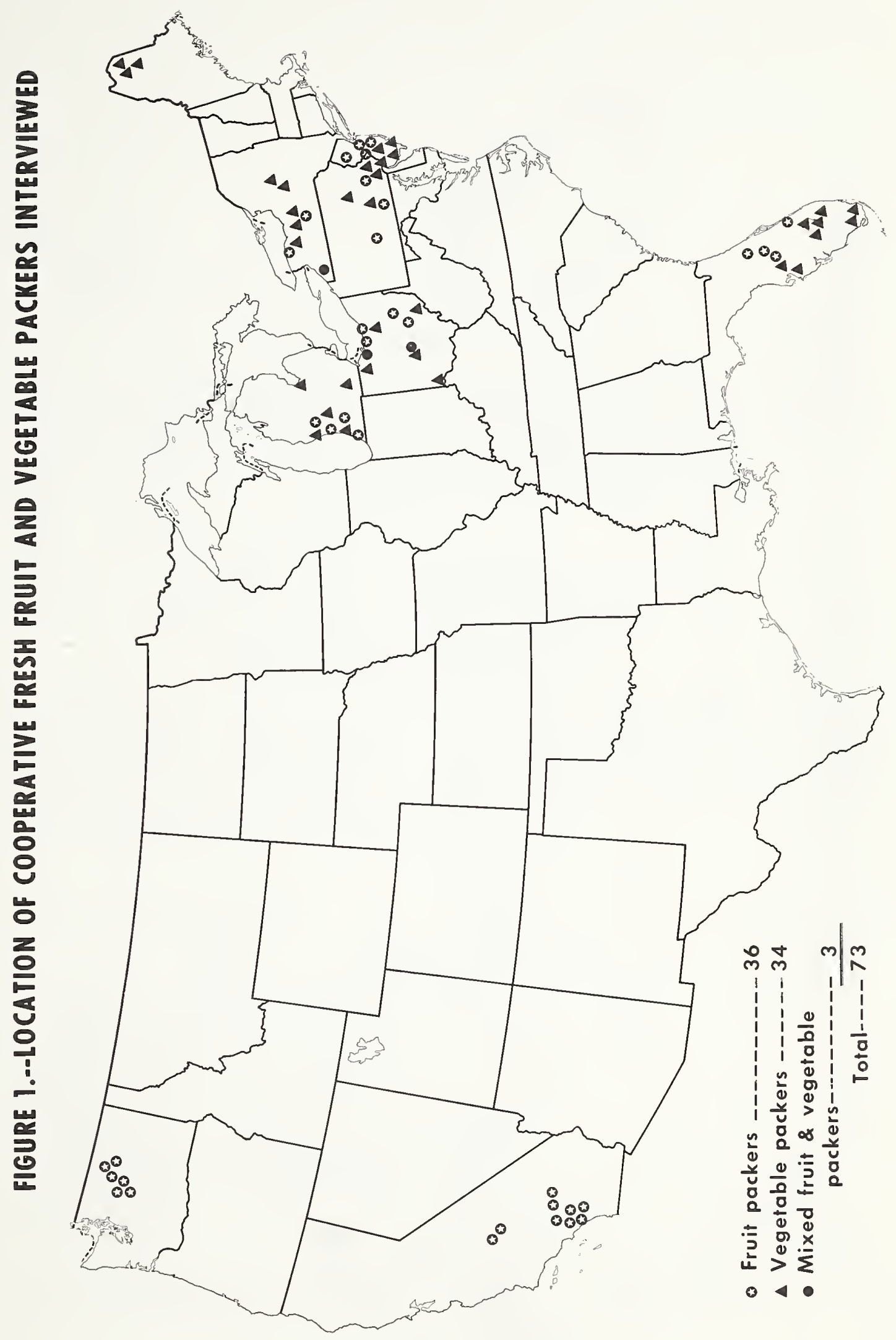




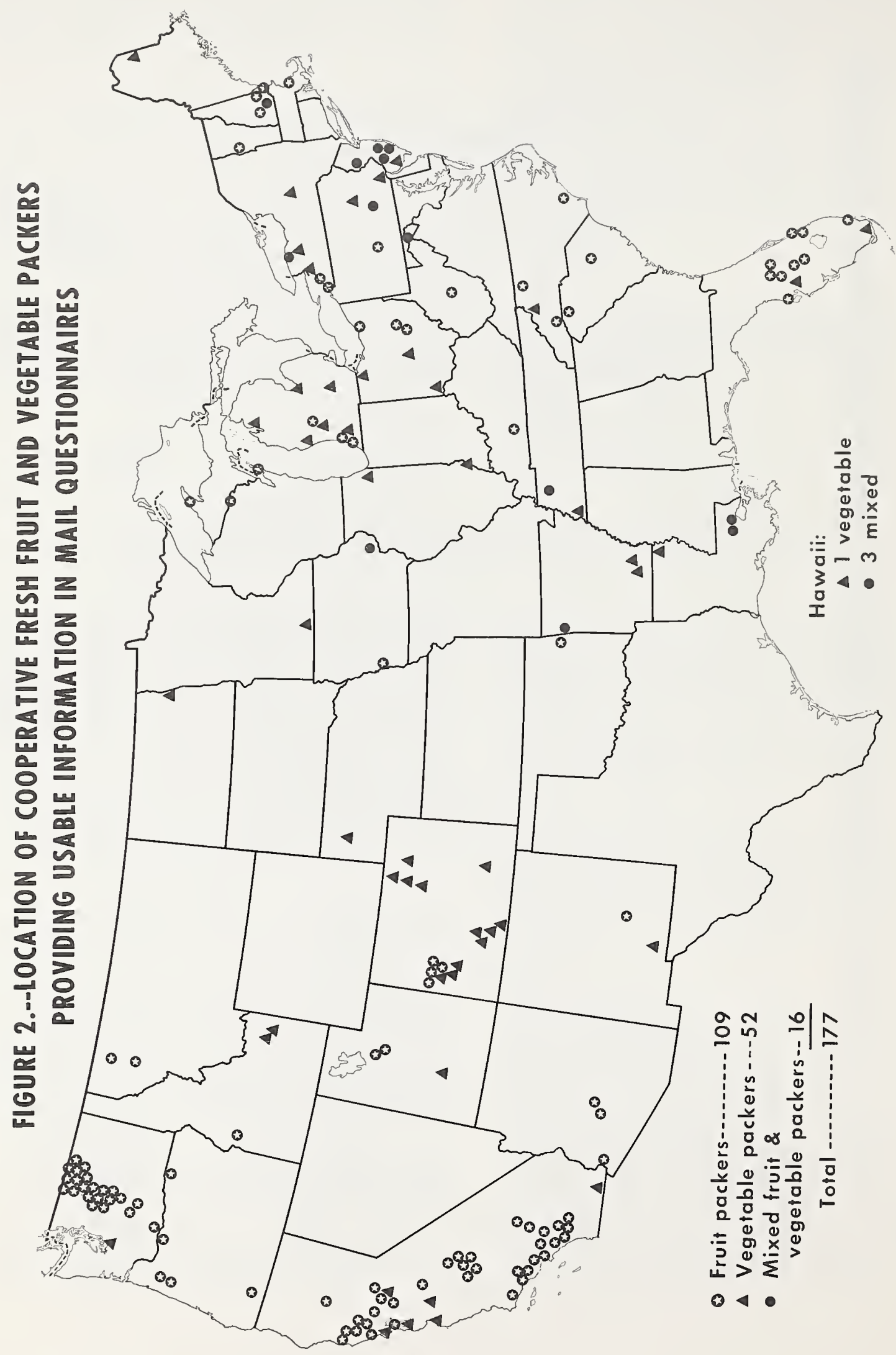


Table 1.-Classification of sales of 188 marketing cooperatives by type of products packed, 1964

\begin{tabular}{l|c|c|c|c|c|c|c|c}
\hline \multirow{2}{*}{ Range in sales } & \multicolumn{2}{|c|}{ Fruit only } & \multicolumn{2}{c|}{ Vegetables only } & \multicolumn{2}{c|}{ Mixed } & \multicolumn{2}{c}{ Total } \\
\cline { 2 - 9 } & No. & Percent & No. & Percent & No. & Percent & No. & Percent \\
\hline \multirow{2}{*}{ Less than $\$ 100,000$} & 15 & 16.3 & 10 & 13.2 & 4 & 20.0 & 29 & 15.4 \\
$100,000-249,999$ & 11 & 12.0 & 13 & 17.1 & 4 & 20.0 & 28 & 14.9 \\
$250,000-499,999$ & 17 & 18.5 & 12 & 15.8 & 8 & 40.0 & 37 & 19.7 \\
$500,000-999,999$ & 25 & 27.2 & 16 & 21.1 & 2 & 10.0 & 43 & 22.9 \\
$1,000,000$ \& over & 24 & 26.0 & 25 & 32.8 & 2 & 10.0 & 51 & 27.1 \\
\cline { 2 - 9 } Total & 92 & 100.0 & 76 & 100.0 & 20 & 100.0 & 188 & 100.0 \\
\hline
\end{tabular}

Table 1 shows the range in sales of marketing co-ops by type of products packed for 188 of the associations in this study. Twenty-seven percent had sales of $\$ 1$ million or over, while 15 percent had sales of under $\$ 100,000$.
Average sales of the 92 associations marketing fruit only were $\$ 934,000$ per association. Average sales of the vegetable cooperatives were $\$ 1,053,000$, and the average for the "mixed" group marketing both types of products was $\$ 510,000$.

\section{CONTAINERS AND PACKAGING SUPPLIES PURCHASED}

The value of the containers and packaging supplies purchased varied considerably among individual marketing cooperatives. This was due to the wide range in sizes of operations, types of produce packed, type and extent of packing operations, and types and sizes of containers or packaging materials used.

\section{ANNUAL CONTAINER COSTS}

Purchases of containers and packaging supplies reported by 180 associations totaled $\$ 17,514,000$, or an average of $\$ 97,300$ per association. The range was from $\$ 200$ to $\$ 500,000$. These costs were thus equal to approximately 10.5 percent of the total sales of products marketed. If this percentage is applied to the estimated total sales of fresh products by all U.S. marketing co-ops, the value of their total purchases of containers and other packaging supplies for marketing fresh fruits and vegetables would be about $\$ 63$ million per year.

Of all cooperatives contacted in the study, 33 percent purchased over $\$ 100,000$ worth of containers and packaging supplies; 39 percent, $\$ 25,000$ to $\$ 100,000$; and 28 percent, less than $\$ 25,000$ (table 2 ). The last group was probably too small to bargain effectively or to qualify for any substantial quantity discounts.

Table 2.-Value of containers and packaging supplies reported purchased by cooperative fresh fruit and vegetable marketing associations, 1964

\begin{tabular}{l|c|c}
\hline \multirow{2}{*}{ Range in purchases } & \multicolumn{2}{|c}{ Cooperatives } \\
\cline { 2 - 3 } & Number & Percent \\
\hline \multirow{2}{*}{ Less than $\$ 1,000$} & 2 & 1.1 \\
$1,000-2,499$ & 3 & 1.7 \\
$2,500-4,999$ & 1 & 0.6 \\
$5,000-9,999$ & 13 & 7.2 \\
$10,000-24,999$ & 31 & 17.2 \\
$25,000-49,999$ & 33 & 18.3 \\
$50,000-99,999$ & 38 & 21.1 \\
100,000 \& over & 59 & 32.8 \\
\hline \multirow{2}{*}{ Total } & 180 & 100.0 \\
\hline
\end{tabular}


In the States other than Florida, California, and Washington, container purchases averaged $\$ 84,728$ per association. Of this amount, approximately $\$ 5,000$ was for packaging supplies other than containers. Approximately 37 percent of these associations purchased containers and packaging supplies for their own use only; 24 percent purchased these items for grower-members' use only; and 39 percent purchased them for the use of both the associations and their grower-members. Average purchases for the three groups in 1964 were $\$ 98,700, \$ 75,400$, and $\$ 85,300$. Fifty-three percent of the purchases of the last group were for the associations' use and 47 percent were for resale to grower-members.

\section{CONTAINER COSTS AS A PERCENTAGE OF TOTAL PACKING COSTS}

Containers and packaging supplies represented the largest single cost in the packing of fruits and vegetables. They averaged 43 percent of the packing costs of fruit and 39 percent of those for vegetables. Forty-six percent of the firms interviewed reported that costs of containers and packaging supplies represented over 50 percent of their total packing costs (table 3). Sixteen percent stated that such costs were over 60 percent of the total.

No fruit packing firms reported packaging costs of less than 30 percent of total packing costs, while 40 percent of the vegetable packing firms reported packaging costs of less than 30 percent. Containers accounted for over 60 percent of the total costs for 23 percent of vegetable co-ops, compared with only 8 percent for fruit co-ops. There was a much wider range of costs for the vegetable packing industry due to differences in the type of pack and type of containers used.

\section{CONTAINER COSTS RELATED TO SALES OF FRESH PRODUCTS}

A comparison between sales of fresh products and container expenditures showed that as sales per packinghouse increased, container costs per firm gradually decreased (curved heavy line in fig. 3). The relationship between volume of sales and container costs per firm was curvilinear. The sales-costs curve increased at a decreasing rate, indicating apparent economies of scale in container procurement; that is, for each 1 percent increase in sales per firm there was less than 1 percent increase in container costs.

When container expenditures were expressed in terms of container costs per dollar of product sales, the relationship became linear (straight broken line in fig. 3). Packing costs per dollar of sales decreased from 10 cents for packinghouses with annual sales of $\$ 100,000$ to 4.6 cents for those having annual sales of $\$ 5$ million.

Table 3.-Percentage of total packing costs reported for containers and packaging supplies, 1964

\begin{tabular}{|c|c|c|c|c|c|c|c|c|}
\hline \multirow{3}{*}{$\begin{array}{l}\text { Percentage that containers } \\
\text { and packaging costs were } \\
\text { of total packing costs }\end{array}$} & \multicolumn{8}{|c|}{ Cooperatives packing specified products } \\
\hline & \multicolumn{2}{|c|}{ Fruits } & \multicolumn{2}{|c|}{ Vegetables } & \multicolumn{2}{|c|}{ Mixed } & \multicolumn{2}{|c|}{ Total } \\
\hline & No. & Percent & No. & Percent & No. & Percent & No. & Percent \\
\hline Less than 10 & - & 0.0 & 1 & 4.6 & 1 & 50.0 & 2 & 5.4 \\
\hline $10-19$ & - & 0.0 & 5 & 22.7 & 1 & 50.0 & 6 & 16.2 \\
\hline $20-29$ & - & 0.0 & 3 & 13.6 & - & 0.0 & 3 & 8.1 \\
\hline $30-39$ & 4 & 30.8 & 2 & 9.1 & - & 0.0 & 6 & 16.2 \\
\hline $40-49$ & 2 & 15.4 & 1 & 4.6 & - & 0.0 & 3 & 8.1 \\
\hline $50-59$ & 6 & 46.2 & 5 & 22.7 & - & 0.0 & 11 & 29.8 \\
\hline 60 and over & 1 & 7.6 & 5 & 22.7 & - & 0.0 & 6 & 16.2 \\
\hline Total & 13 & 100.0 & 22 & 100.0 & 2 & 100.0 & 37 & 100.0 \\
\hline
\end{tabular}


FIG. 3.-- RELATIONSHIP OF SALES OF FRESH FRUITS AND VEGETABLES TO TOTAL CONTAINER COSTS AND TO CONTAINER COSTS PER DOLLAR OF PRODUCT SALES

CONTAINER COSTS PER DOLLAR OF SALES

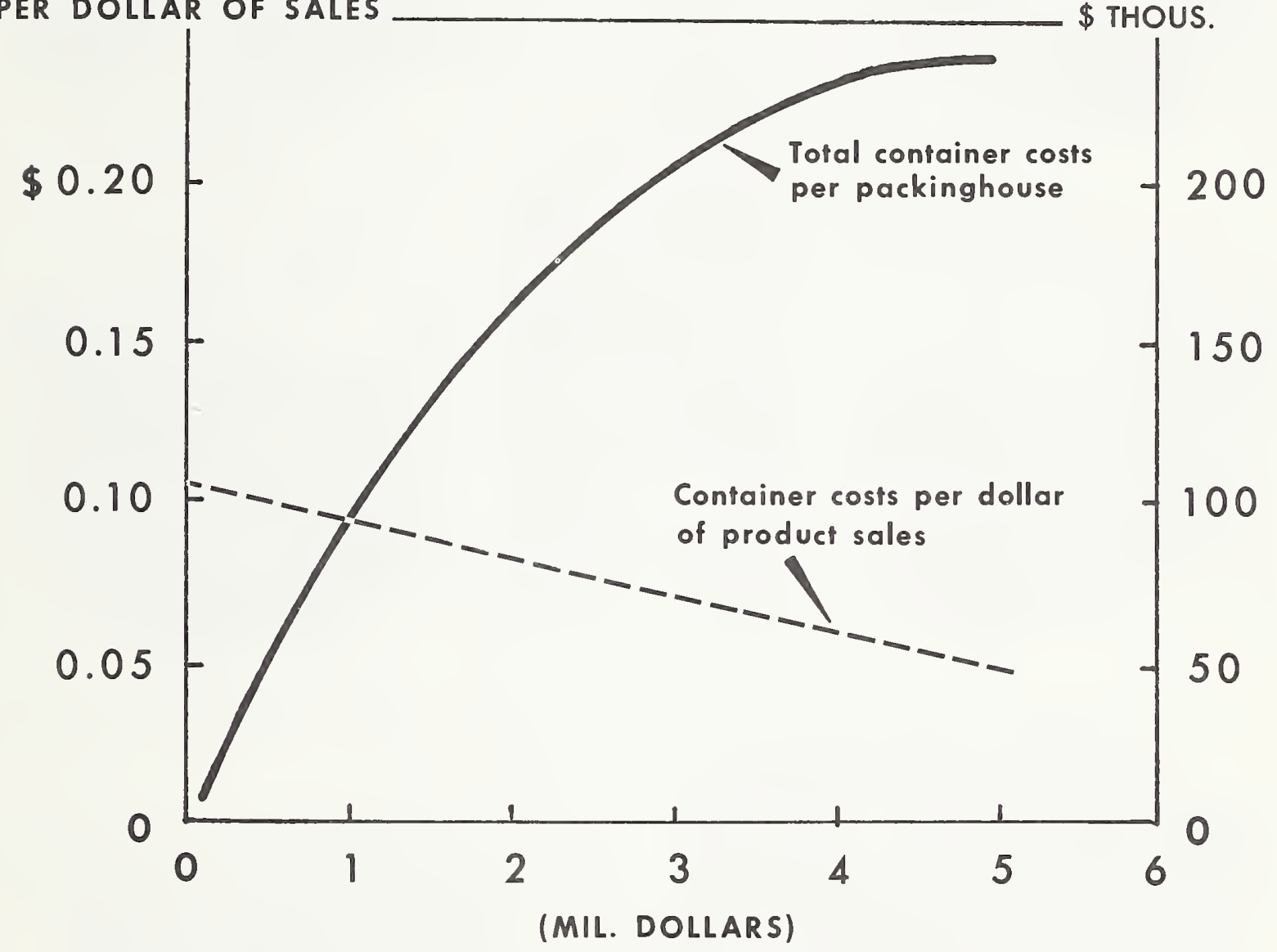

CONTAINER COSTS \$ THOUS. 


\section{TYPES OF CONTAINERS HANDLED AND TRENDS IN CONTAINER USE}

Major shifts in types of containers used for packing fresh fruits and vegetables and trends in standardization affect the potential advantages of cooperative purchase or fabrication of containers.

\section{TYPES OF CONTAINERS HANDLED}

The fresh fruit and vegetable industry, including the cooperatives in this study, uses a great variety of types and sizes of containers and other packaging materials. Basic types used are paperboard cartons and trays; paper bags; wooden boxes, lugs, baskets, crates, tubs, hampers, cups, and pulp trays; burlap and cotton mesh bags; and polyethylene bags.

It was not possible to obtain data on the quantity or value of the various types or classes and sizes of containers purchased by the cooperatives in this study.

In general, information from the cooperatives contacted indicated that the industry is moving away from nailed and wirebound wooden boxes, and wooden hampers, baskets, tubs, or cups to paperboard or other paper products. For strawberries, plastic containers are coming into general use. The same situation exists in bag usage, where the trend is away from burlap or cloth bags to paper and polyethylene or other plastic bagging materials.

Overall, there seems to be little standardization of containers and there are many small variations in what are basically the same containers. However, there appears to be an increasing trend toward standardization of containers for citrus, apples, potatoes, tomatoes, lettuce, asparagus, artichokes, cucumbers, sweet corn, blueberries, and mushrooms. In some States, such as California, Florida, and Arizona, standard container laws exist, but even then slight differences exist in standards among States.

The Agricultural Code of California for example, recently listed 16 commodities without standard containers and 18 commodities with 172 standard containers. The number of containers ranged from 29 for grapes to 4 for all types of citrus and 2 for lettuce and asparagus. California had 4 standard types of containers for citrus, compared with 10 in Florida.
Cooperatives in California packed almost all of their citrus in a standardized paperboard carton, which with small variations is also used for oranges, lemons, and grapefruit. Florida co-ops are rapidly adopting a similar carton, but they still ship a substantial amount in wirebound wooden boxes.

Most apples were packed in corrugated cardboard master containers and in either fiberboard trays, molded pulp consumer packs, or poly bags of various sizes. Co-ops also used bulk cartons of $1,11 / 8$, and $11 / 2$ bushel capacity. Many other deciduous fruits, such as pears, cherries, and plums, are still shipped in wooden lug-type boxes.

Most potatoes were packed in paper bags; the small white 5-, 10-, and 20-pound bags with a window were the most common. Also, a considerable volume was packed in 5- and 10-pound poly and mesh bags. Most seed potatoes were shipped in burlap bags.

There was a wider variation in types and sizes of containers used for vegetables than for fruits. For example, cabbage was packed in traditional wooden crates, corrugated cardboard cartons, mesh bags, and poly bags-all of 50 pounds capacity. Also there were many variations in what were basically the same containers and in their prices. For example, packers reported that they used the following types of wooden bushel baskets: The plain bushel, mill run bushel, bushel with no loops, crush bushel, spinach bushel with a rimless cover, bushel export tub, imperial bushel, bushel cucumber tub, and bushel hamper. Costs ranged from 20.1 to 42.5 cents each.

On the other hand, the packers interviewed packed nearly all of their cucumbers in two sizes of corrugated cardboard boxes: The Senior size with inside dimensions of $181 / 4^{\prime \prime} \times 9^{\prime \prime} \times 511 / 16^{\prime \prime}$ and the Jumbo, $181 / 2^{\prime \prime}$ x $91 / 8^{\prime \prime}$ x $611 / 16^{\prime \prime}$.

Mushrooms were generally packed in wooden 2-quart baskets for the retail trade and in 4-quart (3-pound) wooden baskets for shipment to the cannery. Sweet corn was usually packed in $217 / 8^{\prime \prime} \mathrm{x}$ 12 " $\times 9$ " wirebound wooden crates, and blueberries in standard pint cups with 12 in a wooden master container. Most tomatoes were packed in standard 40-pound paperboard cartons. Greater use was being made of universal-type wirebound crates for other vegetables in California, Washington, and Florida. 


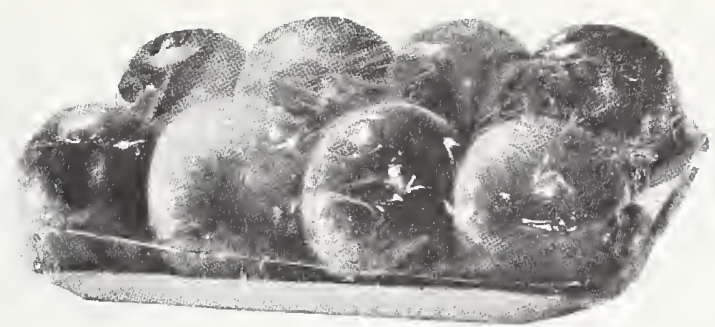

Molded pulp tray

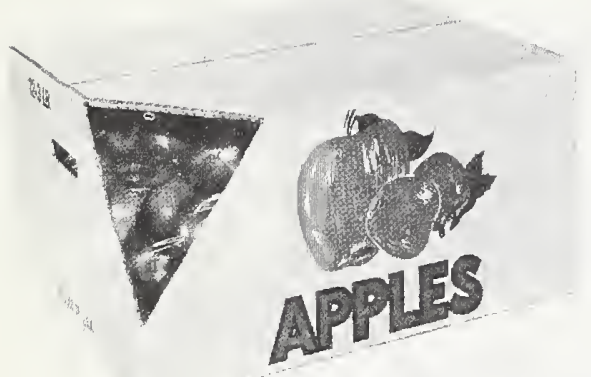

Bag masters

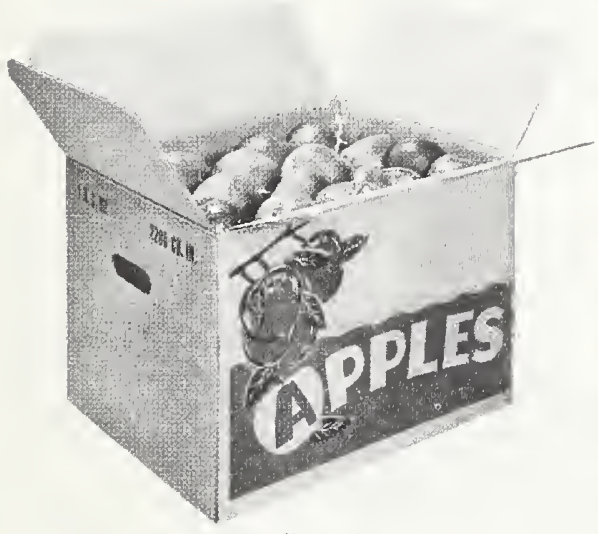

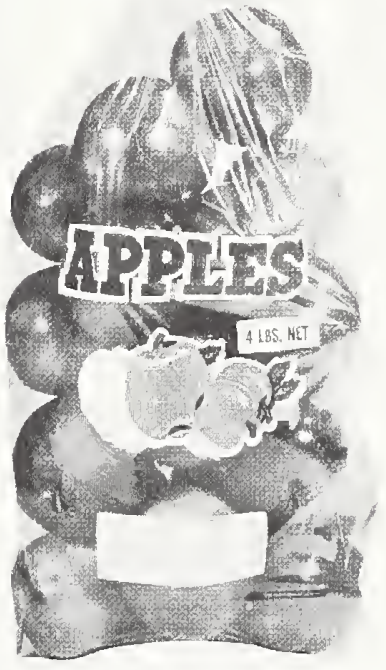

Poly bags for apples

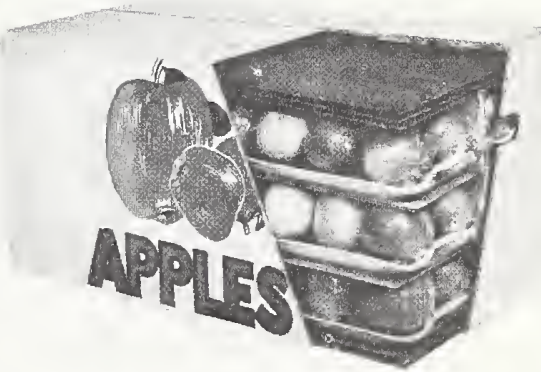

Consumer pack master

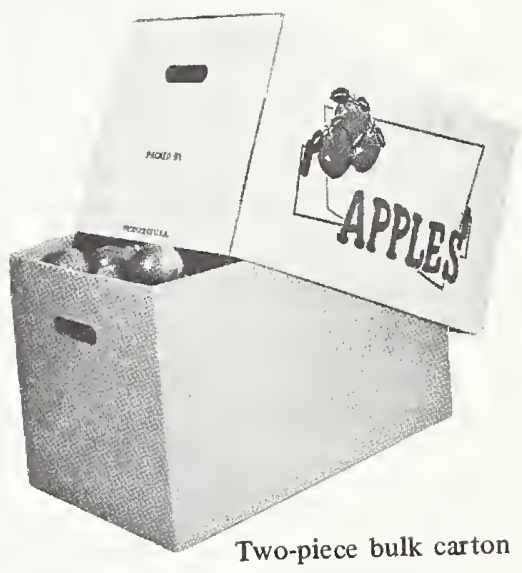

Bulk carton

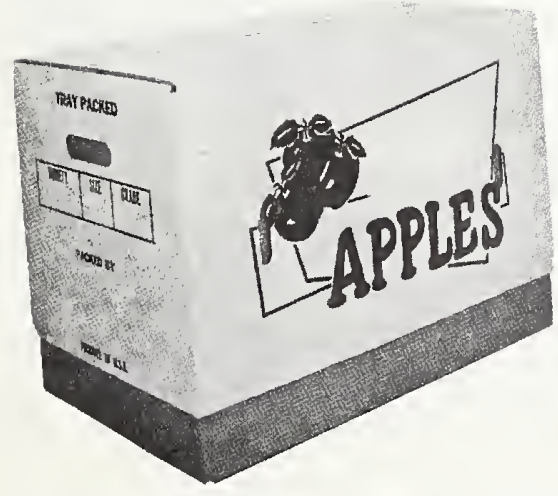

Tray master

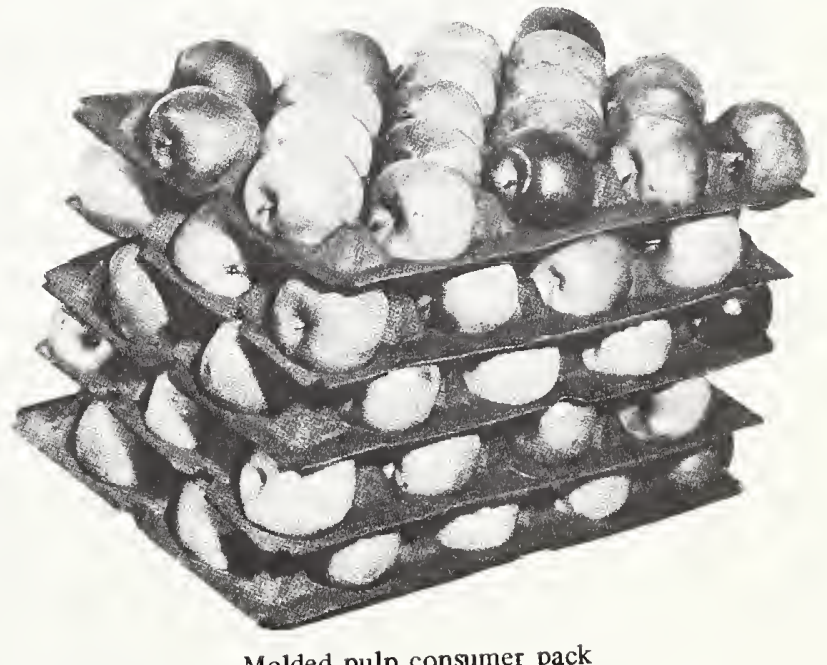

Some shipping containers used by nor theastern apple marketing firms. 


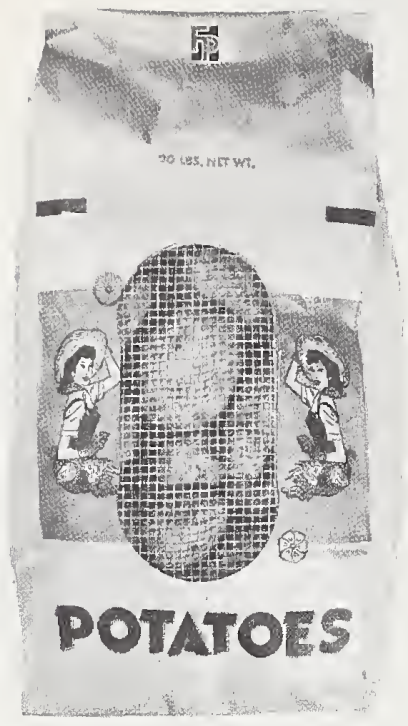

Multiwall produce bags

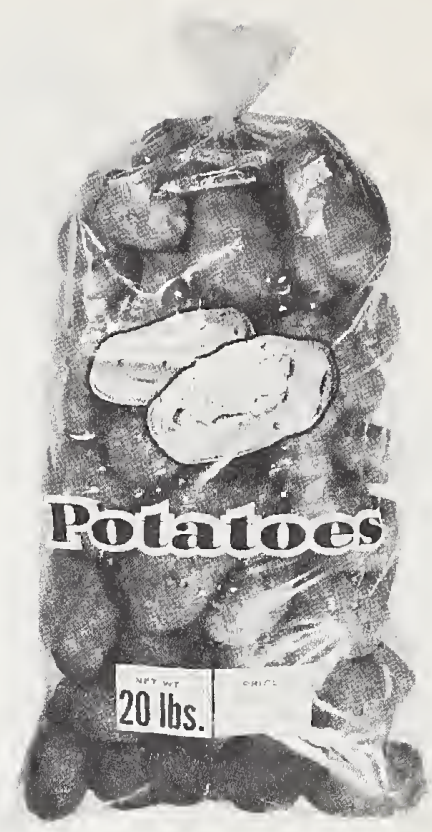

Poly potato bags
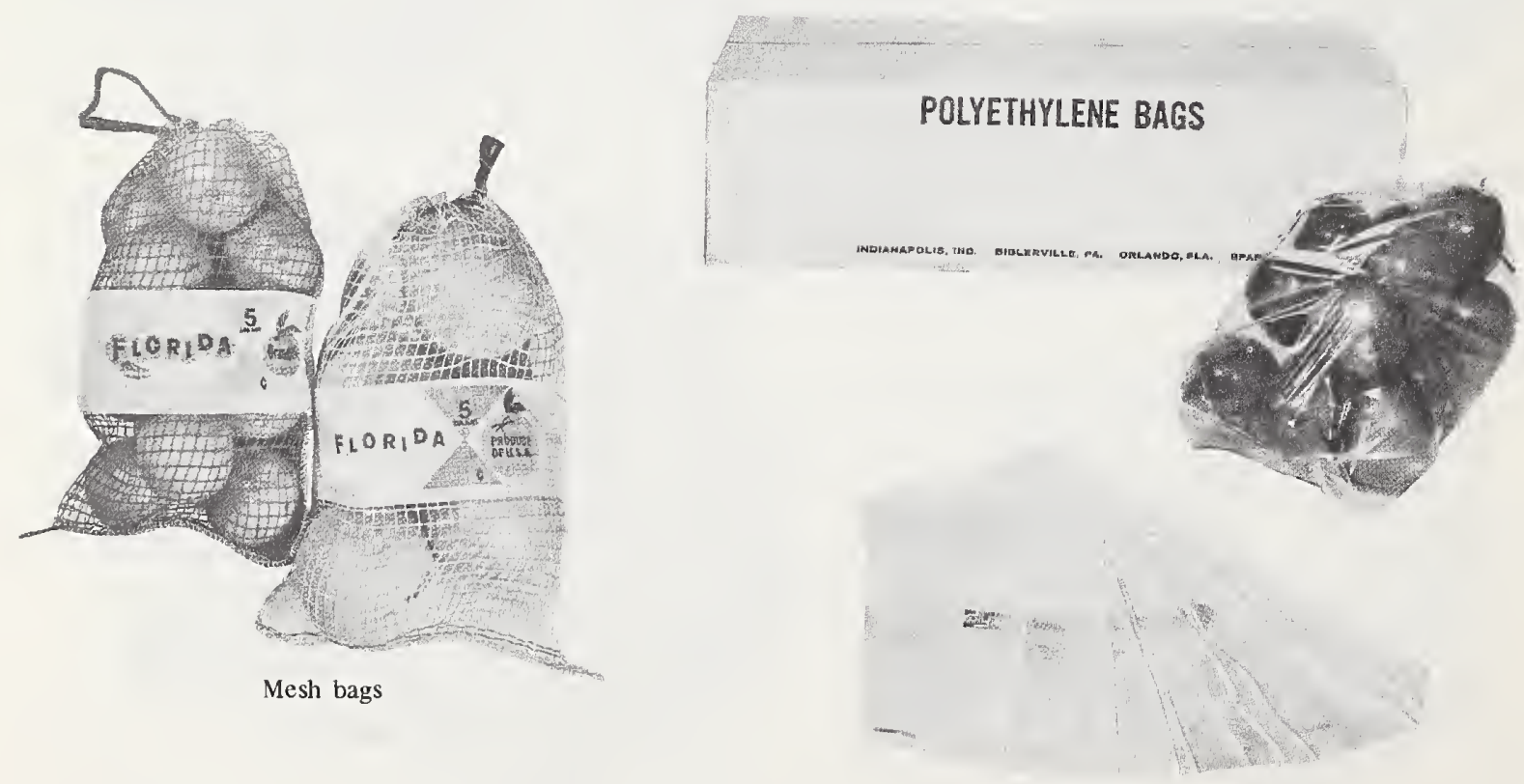

Poly bags and carton

Some containers used by fresh fruit and vegetable marketing firms. 
Representatives of many co-ops reported that there is an increasing trend toward standardization of containers for marketing fresh fruit and vegetables, and that this trend would increase advantages for the cooperative purchase or fabrication of such supplies.

Table 4.-Average annual rates of growth in sales of selected containers and container materials, 1954-63

\begin{tabular}{l|c}
\hline \multicolumn{1}{c|}{ Item } & $\begin{array}{c}\text { Average annual rate } \\
\text { of growth, 1954-631 }\end{array}$ \\
& Percent \\
Fast growth: & 14.3 \\
$\quad$ Plastic products & 7.8 \\
Specialty bags (all materials) & \\
Corrugated and solid fiber boxes & 5.5 \\
Moderate growth: & \\
$\quad$ Wirebound boxes & 2.1 \\
Shipping sacks and multiwall bags & 1.5 \\
& \\
Declining trend: & -0.8 \\
Veneer and plywood containers & -1.2 \\
Box shook & -1.6 \\
Textile bags & 4.9 \\
All containers and packaging materials & \\
\hline
\end{tabular}

${ }^{1}$ Comparable data for the period since 1963 are not available. However, other data series indicate a continuation of the rapid shift toward paperboard and plastic materials. During 1965 and 1966, military activities in Vie tnam caused an increase in the use of most container materials.

${ }^{2}$ Includes cello and polyethylene bags and other specialty materials.

Source: "Containers and Packaging", U.S. Dept. Com., Business and Defense Serv. Admin., Aug. 1965.

\section{INDUSTRY-WIDE TRENDS IN CONTAINER USE}

Although the sample of packers contacted in the study was too small to reflect industry-wide trends in the use of various types of containers and container materials, analysis of data collected by the U.S. Department of Commerce provides an indication of changes in sales of selected types of containers and container material (table 4).

These changes largely have been due to a combination of technological and price changes. The use of plastic products and specialty bags (cello bags and polyethylene bags) has paralleled the growth of the plastics industry in the United States. The visibility offered by plastics and plastic bagging materials, plus prices generally below those of containers made from competing materials have encouraged their use. For example, polyethylene bags are from a quarter to a third cheaper than comparable paper bags.

Table 5 shows comparative price trends for selected containers and container materials. These trends are reflected in use of the types of containers and materials shown. The prices of burlap and other textile bagging have increased substantially during the past 9 years, but the prices of paper and polyethylene bags have decreased. The result has been a shift from burlap and other textile bags to multiwall paper bags and cello or polyethylene materials. The same situation prevails with respect to the competition between wooden boxes and corrugated paperboard cartons. The price of paperboard cartons relative to that for wooden boxes has declined and thus has encouraged the shift from wood to paperboard.

Table 5.-Annual wholesale price indexes for selected containers and container materials, 1958-66 $(1957-59=100$, unless otherwise specified $)$

\begin{tabular}{|c|c|c|c|c|c|c|c|c|c|}
\hline Container item & 1966 & 1965 & 1964 & 1963 & 1962 & 1961 & 1960 & 1959 & 1958 \\
\hline Shipping sacks, multiwall, paper & 99.3 & 94.0 & 90.7 & 92.9 & 98.8 & 98.4 & 99.6 & 99.1 & 101.9 \\
\hline Corrugated paperboard shipping containers $\mathfrak{l}$ & 297.0 & 94.3 & 94.4 & 97.1 & 97.2 & ${ }^{3}$ n.a. & n.a. & n.a. & n.a. \\
\hline Burlap & 156.1 & 138.9 & 113.6 & 117.7 & 132.3 & 133.9 & 113.4 & 97.8 & 98.3 \\
\hline Container board & 97.3 & 96.6 & 97.5 & 94.6 & 92.4 & 91.4 & 99.6 & 100.0 & 100.0 \\
\hline Lumber & 108.9 & 101.9 & 100.7 & 98.9 & 96.5 & 94.7 & 99.8 & 104.5 & 97.0 \\
\hline
\end{tabular}

${ }^{1}$ January $1961=100 . \quad{ }^{2}$ January-June, 1966 only. $\quad{ }^{3}$ Not available. $\quad$ Source: Bureau of Labor Statistics 


\section{EXISTING PROCUREMENT PRACTICES}

The marketing cooperatives were questioned as to sources of their container purchases, and advantages and disadvantages of each type of source; purchasing practices; inventory and storage policies; prices paid; discounts and patronage refunds received; and transportation methods.

\section{SOURCES OF CONTAINERS}

Two types of sources of containers and packaging supplies were reported. In California, Florida, and Washington, cooperative fruit and vegetable packers generally depended on supply cooperatives as their major source of these materials (table 6). In other areas, direct purchase from manufacturers was the most important single source. Purchase from private suppliers, jobbers, or other resale sources was more important in the vegetable packing industry than in the fruit industry, particularly where a variety of vegetables were packed in a single plant.

In some instances packers placed small "courtesy" container orders through local suppliers, or purchased items locally in case of emergency.

\section{Supply Cooperatives}

In California, Florida, and Washington, container purchases from cooperatives were generally tied to a supply department or supply subsidiary of a major cooperative marketing association. Examples are: Sunkist Growers-Fruit Growers' Supply Company, Florida Citrus Exchange-Exchange Supply and Service Company, California Fruit Exchange-CFE Supply Department, and Northwest WholesaleNorthwest Wholesale Supply Department. Marketing co-ops in these States bought over 55 percent of their containers through such sources (table 6).

In most other areas, except Maine where the Maine Bag Company was a part of Maine Potato Growers, cooperative packers were not associated with large regional marketing associations, and thus purchased nearly 80 percent of their containers and packaging supplies directly from manufacturers. Local, private resale suppliers were most important in areas where a variety of produce was packed.

Packers generally tended to concentrate their purchases of containers and packaging materials with one type of supplier. Where packers purchased through cooperatives, they normally purchased all such supplies from this source. Some purchasing contracts of supply cooperatives required that all purchases be made through the cooperative. Although packers who purchased directly from manufacturers were not tied to such suppliers by purchase contracts, three-quarters of them reported that they purchased only from this source.

Of packers who purchased through local suppliers, less than a third depended entirely on this source. In

Table 6.-Sources of containers and packaging supplies purchased by fresh fruit and vegetable marketing cooperatives

\begin{tabular}{|c|c|c|c|c|c|c|}
\hline \multirow[b]{2}{*}{ Source } & \multicolumn{3}{|c|}{ California, Florida, Washington } & \multicolumn{3}{|c|}{ Other States } \\
\hline & $\begin{array}{l}\text { No. of } \\
\text { co-ops }\end{array}$ & $\begin{array}{l}\text { Percent } \\
\text { of total }\end{array}$ & $\begin{array}{c}\text { Percent of } \\
\text { purchases }\end{array}$ & $\begin{array}{l}\text { No. of } \\
\text { co-ops }\end{array}$ & $\begin{array}{l}\text { Percent } \\
\text { of total }\end{array}$ & $\begin{array}{l}\text { Percent of } \\
\text { purchases }\end{array}$ \\
\hline Cooperative suppliers & 60 & 57.1 & 55.6 & 5 & 3.4 & 3.1 \\
\hline Local private suppliers & 3 & 2.9 & 1.9 & 37 & 25.3 & 15.3 \\
\hline Direct from manufacturers & 42 & 40.0 & 42.5 & 117 & 80.1 & 79.1 \\
\hline Other suppliers & 0 & 0 & 0 & 10 & 6.9 & 2.5 \\
\hline Total & 105 & 100.0 & 100.0 & 169 & $(1)$ & 100.0 \\
\hline
\end{tabular}

${ }^{1}$ Some cooperatives bought from more than one source. 
most cases, such packers bought less than 25 percent of their total container requirements from local suppliers. They usually bought only small lots of containers in emergencies or maintained a nominal volume of "courtesy" orders from such suppliers.

The principal reasons for marketing co-ops not purchasing containers and packaging supplies through supply co-ops were: (1) In some areas, there were no supply co-ops; (2) in other areas, supply co-ops did not handle containers; (3) some supply co-ops maintained only a small stock of containers for the convenience of a few of their grower-shipper members and were unable to fill the needs of the marketing co-ops; and (5) the belief that some supply cooperatives were purchasing containers from the same sources as packers, and thus represented an added cost between the container manufacturer and the packer. The general opinion was that growers and packers were getting containers as cheaply as possible from their present sources.

Advantages. - The principal advantage associated with the purchase of containers and packaging supplies from cooperative suppliers was lower cost. Twenty-six percent of the marketing cooperatives believed this was due to lower prices and 48 percent thought it was accomplished by means of patronage refunds (table 7).

Table 7.-Principal advantages listed for purchasing containers and packaging supplies from supply cooperatives

\begin{tabular}{|c|c|c|}
\hline Advantage reported & $\begin{array}{l}\text { Number } \\
\text { of replies }\end{array}$ & $\begin{array}{l}\text { Percent } \\
\text { of total }\end{array}$ \\
\hline \multicolumn{3}{|l|}{ Price } \\
\hline Lower price & 28 & 26 \\
\hline \multicolumn{3}{|l|}{ Service } \\
\hline Very rapid service & 9 & 8 \\
\hline Handles volume & 5 & 5 \\
\hline Dependability & 3 & 3 \\
\hline Subtotal & 17 & 16 \\
\hline \multicolumn{3}{|l|}{ Convenience } \\
\hline Keeps inventory down & 1 & 1 \\
\hline Local supply point & 2 & 2 \\
\hline Subtotal & 3 & 3 \\
\hline \multicolumn{3}{|l|}{ Product } \\
\hline Better quality & 8 & 7 \\
\hline \multirow[t]{2}{*}{ Patronage refund } & 53 & 48 \\
\hline & 109 & 100 \\
\hline
\end{tabular}

Other reasons, including very rapid service, dependability, and volume operation were next in importance, and accounted for 16 percent of advantages listed. Better quality and convenience were also listed as advantages.

Disadvantages.-In areas where containers and packaging supplies were available through supply cooperatives, the managers of marketing cooperatives gave the following as disadvantages and problems associated with such purchases: Poor service was most frequently mentioned--accounting for 60 percent of the disadvantages listed; slow or poor service; insufficient stock on hand; lack of desired types of containers; less convenient than local supply; and the desire to not be dependent on one supplier also were mentioned (table 8).

Table 8.-Principal disadvantages reported for purchasing containers and packaging supplies from supply cooperatives

\begin{tabular}{|c|c|c|}
\hline Disadvantage reported & $\begin{array}{l}\text { Number } \\
\text { of replies }\end{array}$ & $\begin{array}{l}\text { Percent } \\
\text { of total }\end{array}$ \\
\hline \multicolumn{3}{|l|}{ Price } \\
\hline $\begin{array}{l}\text { Prices higher than those of } \\
\text { manufacturers }\end{array}$ & 8 & 19 \\
\hline $\begin{array}{l}\text { Smaller discount than from } \\
\text { manufacturers }\end{array}$ & 2 & 4 \\
\hline Subtotal & 10 & 23 \\
\hline \multicolumn{3}{|l|}{ Service } \\
\hline Slow or poor service & 7 & 16 \\
\hline Do not stock desired product & 6 & 13 \\
\hline Insufficient stock on hand & 3 & 7 \\
\hline $\begin{array}{l}\text { Less convenient than local } \\
\text { supplier }\end{array}$ & 6 & 13 \\
\hline $\begin{array}{l}\text { Too much dependence on } \\
\text { one supplier }\end{array}$ & 5 & 11 \\
\hline Subtotal & 27 & 60 \\
\hline \multicolumn{3}{|l|}{ Quality } \\
\hline $\begin{array}{l}\text { Can't get quality wanted } \\
\text { from co-op }\end{array}$ & 2 & 4 \\
\hline Other reasons & 6 & 13 \\
\hline Total & 45 & 100 \\
\hline
\end{tabular}


Price reasons, including higher prices than those of manufacturers and smaller discounts than from manufacturers, accounted for 23 percent of the total disadvantages reported. Quality problems, personality conflicts, and other miscellaneous disadvantages made up 17 percent of the total.

\section{Private Suppliers}

In States other than California, Florida, and Washington, 15 percent of all containers purchased by cooperative packers contacted were purchased through local jobbers or other private resale suppliers. In California, Florida, and Washington, very little use was made of this type of supplier.

Advantages.-Service and convenience were the principal reasons associated with purchase from private suppliers. Better service in general and the availability of special service on small orders or the stocking of specialty containers were more specific reasons listed.

Disadvantages.-Price was the most frequently mentioned disadvantage in dealing with private suppliers. Inadequate inventories of containers and packaging supplies, lack of warehouse facilities, and the inability of small private suppliers to give complete service were also cited. Larger packers also thought that they could purchase directly from manufacturers on the same terms as the private suppliers.

\section{Direct From Manufacturers}

Purchase of containers and packaging supplies directly from manufacturers was the most common practice among fresh fruit and vegetable marketing co-ops contacted, accounting for 58 percent of all such supplies purchased. However, in California, Florida, and Washington, co-ops bought only 40 percent direct from manufacturers (compared with 60 percent from container) supply co-ops.

Advantages. - Price was the most important reason listed for the purchase of containers direct from manufacturers; it was mentioned by 65 percent of the associations purchasing from such firms (table 9). The reason mentioned most frequently was lowest price available-by 46 percent of the group. Lowest price because of competitive bids among manufacturers, lowest price because of the elimination of middlemen, carload prices, and greater discounts also were listed as price reasons.

Service and product reasons were equal in importance. Eleven percent felt they could obtain the best service and delivery directly from manufacturers because the latter distribute directly from their own warehouses and have sufficient stock available at all times. Thirty-four percent of packers contacted mentioned product reasons, such as: Containers were made to their specifications, good quality in general, or guaranteed quality.

Credit was not listed as an important advantage for dealing with manufacturers, because 95 percent of the cooperatives contacted took advantage of available cash discounts from all supply sources.

Disadvantages.-Generally, cooperative packers were quite satisfied with their relationships with the manufacturers. Only 32 percent of the cooperatives purchasing directly from manufacturers mentioned any disadvantage in dealing with this source.

The principal disadvantages mentioned pertained to service, such as slow deliveries and accumulation of large inventories when manufacturers required that they purchase in large quantities (table 10).

\section{PURCHASING PRACTICES}

Packers were questioned in detail regarding their purchasing practices in an effort to identify the methods used, resale of containers to their growermembers, and container storage and inventory management.

Thirty-nine percent of all cooperatives contacted purchased containers and packaging supplies only for their own use. Of the remaining 61 percent, 23 percent purchased containers only for use of growermembers who field-packed their products, and 38 percent purchased both for association use and grower-members' use (table 11). Purchase for resale to members was most common among vegetable packers, especially where field-packing was the general practice. 
Table 9.-Advantages reported by cooperatives for purchasing containers and packaging supplies direct from manufacturers

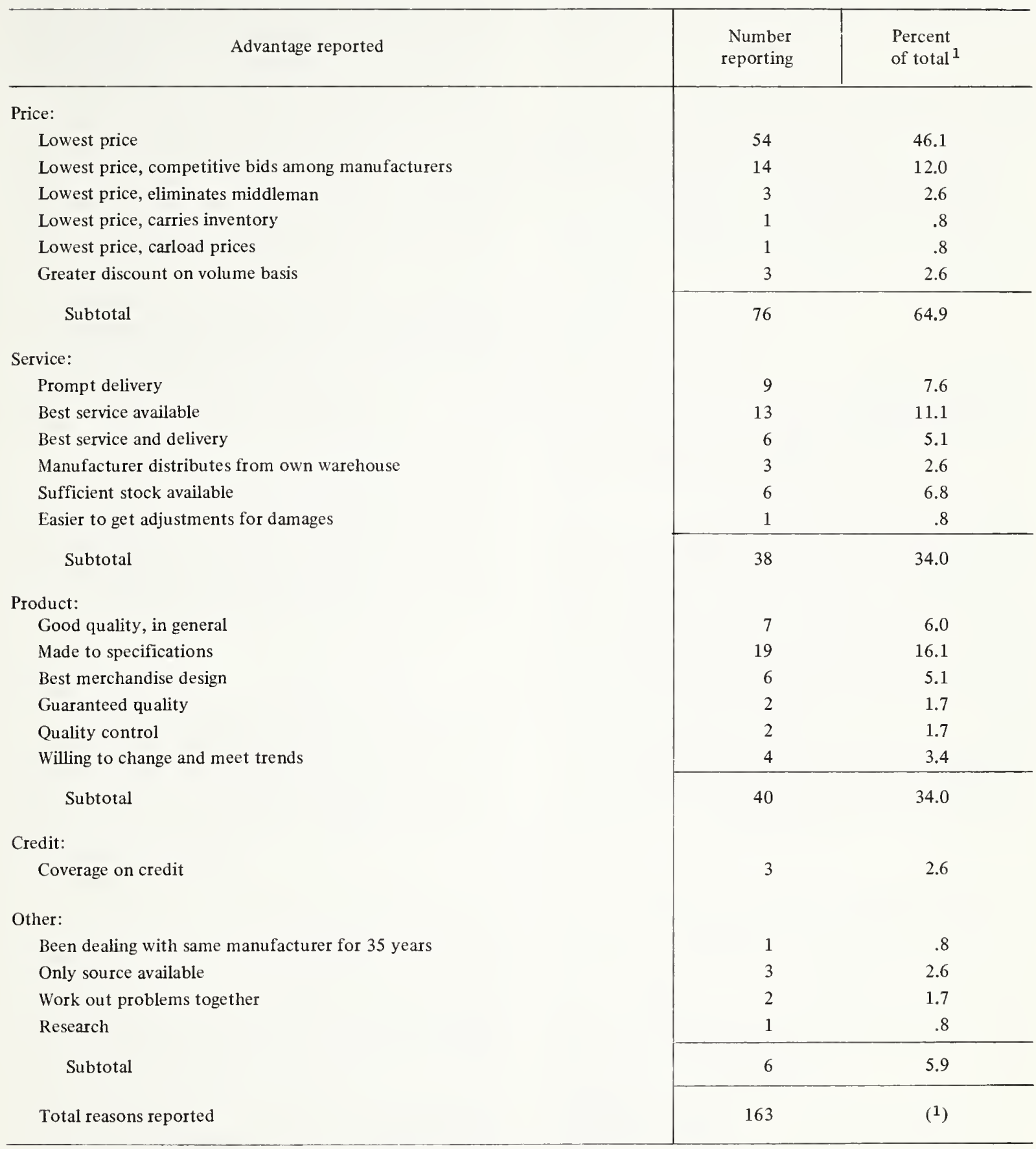

${ }^{1}$ Total exceeds 100 percent because two or more items were listed by many cooperatives. 


\begin{tabular}{|c|c|c|}
\hline Disadvantage reported & $\begin{array}{l}\text { Number } \\
\text { reporting }\end{array}$ & $\begin{array}{l}\text { Percent } \\
\text { of total }^{1}\end{array}$ \\
\hline \multicolumn{3}{|l|}{ Price: } \\
\hline If manufacturer has local distributor, you lose price advantage & 1 & .9 \\
\hline $\begin{array}{l}\text { Do not approve of price-cutting policies employed by manufacturers } \\
\text { in competitive bidding }\end{array}$ & 1 & .9 \\
\hline All manufacturers are operating at same price & 1 & .9 \\
\hline Hard to determine prices & 1 & .9 \\
\hline Subtotal & 4 & 3.6 \\
\hline \multicolumn{3}{|l|}{ Service: } \\
\hline Slower on deliveries & 7 & 6.0 \\
\hline Must buy in large quantities & 10 & 8.5 \\
\hline Have to carry larger inventory & 6 & 5.1 \\
\hline Tends to forget little man and serves large customer first & 1 & .9 \\
\hline Big companies get unwieldy & 1 & .9 \\
\hline Too many salesmen & 2 & 1.8 \\
\hline Manufacturer does not have local warehouse & 1 & .9 \\
\hline Subtotal & 28 & 23.9 \\
\hline \multicolumn{3}{|l|}{ Credit: } \\
\hline Poor credit policy - no seasonal terms & 1 & .9 \\
\hline \multicolumn{3}{|l|}{ Other: } \\
\hline $\begin{array}{l}\text { Manufacturer may go out of business or go on strike, then } \\
\text { we must put up for rebids }\end{array}$ & 2 & 1.8 \\
\hline Occasionally produces poor product & 1 & .9 \\
\hline Subtotal & 3 & 2.7 \\
\hline Total items reported & 37 & (1) \\
\hline
\end{tabular}

${ }^{1}$ Total exceeds 100 percent because two or more items were listed by many cooperatives.

Table 11.-Cooperatives' purchasing practices for containers and packaging supplies

\begin{tabular}{l|c|c}
\hline \multicolumn{1}{c|}{ Purchasing practice } & $\begin{array}{c}\text { Number } \\
\text { reporting }\end{array}$ & $\begin{array}{c}\text { Percent } \\
\text { of total }\end{array}$ \\
\hline $\begin{array}{l}\text { Buy only for association's own use } \\
\text { Buy only for use of grower-members }\end{array}$ & 66 & 39 \\
$\begin{array}{l}\text { Buy both for association use and for } \\
\text { grower-members' use }\end{array}$ & 64 & 38 \\
\cline { 2 - 3 } Total & 168 & 100 \\
\hline
\end{tabular}

\section{Resale of Containers to Grower-Members}

Of the 38 associations that resold containers to grower-members, the average resale value per association was $\$ 81,000$. Sales varied from under $\$ 10,000$ to over $\$ 100,000$. Only 11 of the larger firms provided information concerning the resale margin under which they normally operate. The majority of these firms operated on a cost-of-handling basis with margins ranging from 1 to 15 percent, depending on the cost of the resale operation and the policy of the co-op. 
The extent of these operations varied with the individual cooperatives. Most acted only as a broker and placed the order for the grower with the supplier delivering directly to the grower. They attempted to order a full truckload of containers and then arranged for them to be delivered directly to the growers, or to have the grower pick up containers directly from the manufacturer's truck. Other associations estimated the demand, placed the order, accepted the delivery, maintained an inventory, and then sold the containers directly to the grower, sometimes delivering to him.

Under both methods, the cooperatives usually paid the manufacturers directly for the shipment and took advantage of the cash discount. Some then extended credit to the grower till the harvest was well under way or the harvest season was complete.

The average operating margin on container resales reported by the 11 marketing cooperatives was 5.9 percent. However, the average value of the containers and packaging supplies resold to grower-members by these 11 associations was $\$ 103,800$-somewhat higher than the average of all firms interviewed.

\section{Joint Purchases}

None of the fruit and vegetable packers contacted had made joint purchases of containers or other packaging supplies with other packers. These packers cooperated only to the extent of sometimes buying containers from one another to relieve a temporary undersupply or oversupply.

One packer indicated that joint purchases had been made in the past but the practice had been discontinued because it was difficult to coordinate the orders and to realize a saving in price. No other specific reasons were given for not making joint purchases except that packers could see no advantage in attempting such arrangements.

\section{Frequency of Purchases}

In general, cooperative packers of fresh fruits and vegetables purchased containers on a continuing basis throughout the packing season. Thirty percent of the associations interviewed indicated they could get delivery on container orders in 1 day or less, and over 80 percent could expect delivery within 2 weeks (table 12). With relatively rapid service on orders, it generally was not necessary for the cooperative to carry large inventories of containers and packaging supplies.

Table 12.-Order-to-delivery time for containers and packaging supplies purchased

\begin{tabular}{l|c|c}
\hline Order-to-delivery time & $\begin{array}{c}\text { Number } \\
\text { reporting }\end{array}$ & $\begin{array}{r}\text { Percent } \\
\text { of total }^{1}\end{array}$ \\
\hline 1 day or less & 24 & 30 \\
$2-7$ days & 27 & 34 \\
$8-14$ days & 11 & 14 \\
$15-30$ days & 6 & 8 \\
31 days or more & 11 & 14 \\
\hline
\end{tabular}

\footnotetext{
${ }^{1}$ Total number exceeds number of reporting cooperatives because of different order - delivery time for different types of containers and packaging supplies.
}

Table 13 shows the factors influencing the frequency of purchase and receipt of containers and packaging supplies, and the managers' rating of such factors. Seasonal volume of packing operations was the most important factor--mentioned by 58 percent of the managers interviewed. On a scale of 0 to 100 , with 100 as the most important factor, managers rated seasonality of packing operations 96, clearly establishing this reason as the most important. Inventory cost was the second most important factormentioned by 40 percent of the managers. Available warehouse space and suppliers' delivery times also were mentioned.

Table 13.-Factors influencing frequency of purchase and receipt of containers and packaging supplies

\begin{tabular}{l|c|c|c}
\hline \multicolumn{1}{c|}{ Factor } & $\begin{array}{r}\text { Number } \\
\text { reporting }\end{array}$ & $\begin{array}{c}\text { Percent } \\
\text { of total }\end{array}$ & $\begin{array}{c}\text { Manager's } \\
\text { rating }^{1}\end{array}$ \\
\hline $\begin{array}{l}\text { Seasonal volume of packing } \\
\text { operations }\end{array}$ & 42 & 58 & 96 \\
Warehouse space available & 19 & 26 & 25 \\
$\begin{array}{l}\text { Inventory cost } \\
\text { Supplier's order-to-delivery } \\
\text { time }\end{array}$ & 21 & 40 & 42 \\
$\begin{array}{l}\text { Purchase as needed } \\
\text { Order early in season, then } \\
\text { more later if needed }\end{array}$ & 13 & 29 & 32 \\
\end{tabular}

\footnotetext{
${ }^{1}$ Rated on a scale of 0 to 100 , where 100 equals most important factor.
} 
Eighteen percent of the managers indicated that they made one large order or estimate early in the season, so that the manufacturer would have some indication of the season's demand. They would then generally receive delivery on the basis of this order as needed throughout the season, and order additional containers as necessary.

Generally, there existed a close working relationship between the container supplier and the packer. Because of fluctuating seasonal demands, variations in sales orders for fresh-packed produce, and other factors causing fluctuations in the number and type of containers used, the supplier and the packer maintained daily or at least weekly contact to ensure that a supply of containers would be in the packer's hands when needed.

\section{INVENTORY AND STORAGE POLICIES AND PROBLEMS}

Management of inventories and adequacy of storage space for containers and packaging supplies did not present a serious problem for most of the marketing cooperatives contacted.

\section{Inventory Policies and Practices}

Suppliers generally made prompt and reliable delivery of containers, due more to the intense competition among suppliers than to the bargaining power of the cooperative packers. As a result, packers normally carried only an operating inventory and reordered throughout the packing season.

Fresh fruit and vegetable marketing cooperatives' normally carried over small inventories of containers and packaging supplies from one year to the next. Their average beginning inventory was $\$ 9,004$ in 1964, which represented 9.3 percent of total purchases for that year (table 14).

Table 14.-Value of cooperatives' inventories and purchases of containers and packaging supplies in 1964

\begin{tabular}{l|r}
\hline \multicolumn{1}{c|}{ Item } & Average \\
\hline Beginning inventory & $\$ 9,004$ \\
Purchases & 97,300 \\
Ending inventory & 8,958 \\
\hline
\end{tabular}

Ending inventory was slightly lower with an average of $\$ 8,958$, or 9.2 percent of total purchases for the year.

Purchases of containers averaged $\$ 97,300$ per cooperative and total sales for these same firms averaged $\$ 937,000$. Therefore, total container purchases averaged 10.4 percent of total sales, with beginning and ending inventory representing slightly less than 1 percent of total sales.

\section{Storage Practices and Problems}

About one-third of the marketing cooperatives used less than 1,000 square feet of storage space for containers and packaging supplies and an additional 40 percent reported they used less than 5,000 square feet (table 15). Another 22 percent reported use of 5,000 to 9,999 square feet, and only 4 percent utilized over 10,000 square feet of storage space.

Nearly all of the packers interviewed indicated that they did not consider storage space as a limiting factor in determining the quantity of containers purchased at one time even though 74 percent reported using less than 5,000 square feet of storage space. The reason-packers normally carry only an operating inventory and reorder on a continual basis. Also, whenever possible they arrange for delivery direct to the grower-packer engaged in field-packing operations.

Table 15.-Storage space used for containers and packaging supplies, fresh fruit and vegetable marketing cooperatives, 1964

\begin{tabular}{l|c|c}
\hline \multicolumn{1}{c|}{ Storage space used } & $\begin{array}{c}\text { Number } \\
\text { reporting }\end{array}$ & $\begin{array}{r}\text { Percent } \\
\text { of total }\end{array}$ \\
\hline \multicolumn{1}{c|}{ Square feet } & & \\
Less than 1,000 & 24 & 33.8 \\
$1,000-2,499$ & 18 & 25.4 \\
$2,500-4,999$ & 10 & 14.1 \\
$5,000-9,999$ & 16 & 22.5 \\
$10,000-14,999$ & 2 & 2.8 \\
15,000 or more & 1 & 1.4 \\
\hline \multirow{2}{*}{ Total } & 71 & 100.0 \\
\hline
\end{tabular}




\section{TRANSPORTATION METHODS}

Containers and packaging supplies were normally transported from suppliers' plants and warehouses by truck. An estimated 78 percent of such supplies were transported in full truckload lots and 8 percent were transported in less than truckload lots. Cardboard cartons and boxes generally were shipped in full truckload lots; and bags, berry baskets, tills, wraps, and other minor packaging supplies were often delivered in less than full loads.

In the areas of concentrated fruit and vegetable production, packers were normally located within 50 miles of the supplier's plant or warehouse. In these situations, containers and packaging supplies were priced on a uniform delivered basis, unless some unusual circumstance existed. Further, the intense competition in these areas among container suppliers tended to minimize transportation costs to the packers and made available more rapid service. For example, the Maine Bag Company maintains nine trucks to deliver containers and packaging supplies to its member-patrons. Its goal is to "provide the best possible service." The resulting effect is that packers are able to order and receive delivery "as needed," which many times is not in full truckload lots.

Rail movement accounted for an estimated 14 percent of the containers and packaging supplies purchased by cooperatives contacted. Generally, containers for rail shipments were wirebound boxes or wooden crates in full carlots of 10,000 containers per car.

Since virtually all containers were priced on a delivered basis, packers had little information on transportation costs for these items. Cooperatives packers had few suggestions for reducing transportation costs on containers and packaging supplies. They thought such costs were as low as possible and did not present any serious problem. Some felt that it was up to the suppliers to reduce costs.

\section{FACTORS DETERMINING PRICES PAID}

Method of buying, various types of discounts and allowances, and year-end patronage refunds affected the final or net prices the cooperative packers paid for containers and related supplies.

\section{List vs. Negotiated Prices}

Forty-one percent of the fresh fruit and vegetable marketing cooperatives reported the purchase of containers and packaging supplies at negotiated prices. The remaining 59 percent reported purchases at the supplier's established list price. Of the packers who purchased from manufacturers with established list prices, most thought that prices were as low as possible and that price lists were uniform among the various manufacturers.

Competitive considerations were the major factors considered in arriving at negotiated prices. Competitive bidding among manufacturers was based on quantity and specification of the containers, delivery date, terms of payment, quality, and printing service.

\section{Discounts on Purchases}

Purchase discounts have become an integral part of the pricing of containers and packaging supplies. Discounts for prompt payment are normally expected. Other discounts, such as brokerage allowances, special quantity or trade discounts, and storage allowances are more often subject to negotiation.

\section{Cash Discounts}

Ninety percent of the cooperatives contacted reported the availability of various types of cash discounts. Generally the discounts followed a consistent pattern-1 to 2 percent for payment within 10 days after billing (table 16). However, 9 percent of those cooperatives reporting available discounts indicated that their cash discount ranged from more than 2 percent to as high as 10 percent in one case.

Various types of paper and poly bags, cardboard cartons, and miscellaneous packaging supplies such as paper liners, wrappers, and ties generally carried a 1 percent cash discount. Wooden crates, baskets, and boxes generally carried 2 percent or more.

Ninety-five percent of the cooperatives reporting cash discounts indicated that they took advantage of them. Of those that did not take advantage of the discounts, slightly over half reported this was due to a shortage of working capital. Others reported that at the beginning of the season they frequently were unable to pay the supplier because the growers were slow to pay. 
Table 16.-Discount rates allowed for prompt payment for purchascs of containers and packaging supplies

\begin{tabular}{ll|r|r}
\hline & Rate and basis & $\begin{array}{r}\text { Number } \\
\text { reporting }\end{array}$ & $\begin{array}{r}\text { Percent } \\
\text { of total }\end{array}$ \\
\hline Percent & Time in days & & \\
1 & 10 net 30 & 113 & 54.8 \\
1 & 30 & 4 & 1.9 \\
1 & 90 & 4 & 1.9 \\
$1-2$ & 10 net 30 & 15 & 7.3 \\
2 & 10 net 30 & 51 & 24.8 \\
2 & 15 & 1 & 0.5 \\
$1-5$ & 10 net 30 & 11 & 0.5 \\
$2-5$ & 10 net 30 & 1 & 0.5 \\
$2-5$ & 30 & 7 & 3.4 \\
5 & 10 net 30 & 7 & 3.4 \\
6 & 10 net 30 & 1 & 0.5 \\
10 & when shipped & 1 & 0.5 \\
\cline { 3 - 4 } & & 206 & 100.0 \\
\hline
\end{tabular}

Normally, cooperatives used the discount for operating capital, and in turn offered a cash discount on containers resold to their members. It was not uncommon, however, for the cooperatives to carry growers until the harvest was completed or at least until it was well underway.

\section{Trade or Quantity Discounts}

Trade or quantity discounts were available to 141 , or 59 percent, of the reporting cooperatives. However, only about half reported the specific type of discount received (table 17). The most common form was the straight quantity discount, which typically was 5 percent, rather than a graduated or progressive discount. Manufacturers normally offered their discounts on truckload lots of standard stock items, including solid (without window) paper bags, corrugated cardboard containers, and wooden containers.

The supply cooperatives that resold containers to their grower-members frequently were allowed a 5 percent brokerage allowance. This was normally held by the association and net savings remaining above operating costs were returned to members at the end of the year as patronage refunds.

Occasionally marketing cooperatives were allowed a quantity discount of 5 percent and an additional discount of approximately 5 percent as a brokerage allowance. These discounts were in addition to the normal cash discounts, and were most often allowed on large purchases. This shows the possible advantages which cooperative packers might gain through large-scale consolidated purchases of containers and packaging materials.

Progressive discounts were not found for major containers, but did exist for such items as onion bags and berry baskets. For example, one supplier gave the following discounts on onion bags: $\$ 4.50$ per thousand if 5,000 purchased; $\$ 5.50$ for 10,$000 ; \$ 6.50$ for 25,000 ; and $\$ 7.50$ for 50,000 .

\section{Warehouse and Other Allowances or Discounts}

Eighty-five percent of the cooperatives reporting availability of trade or quantity discounts took advantage of such allowances. Of those associations where such discounts were available but not taken, 57 percent reported that they did not buy in large enough quantities or that their operation was too small and seasonal to take advantage of the discounts (table 18). An additional 25 percent reported that they had insufficient warehouse space to buy in large enough lots. Other reasons given were the difficulty in anticipating quantity required or the uncertainty of fresh fruit or vegetable crops. These reasons, they felt, made quantity buying unwise.

Fifteen percent of the cooperatives reported the availability of warehouse allowances or early-season discounts (table 17). The most common rate was 0.65 percent per month for delivery of containers in off-season months. Billing was delayed until November 1. A maximum of 6 months' storage, or 3.9 percent, was allowed under this arrangement. Another two percent of the co-ops reported the availability of other discounts such as $1 / 2$ cent per crate if packer unloads, or an arrangement were unused containers are carried on the supplier's inventory at no cost to the packer. 
Table 17.-Quantity discount rates, brokerage allowances, and warehouse allowances, and other allowances given co-ops on purchases of containers and other packaging supplies in 1964

\begin{tabular}{|c|c|c|}
\hline Discount or allowance and rate and terms & $\begin{array}{r}\text { Number } \\
\text { reporting }\end{array}$ & $\begin{array}{l}\text { Percent } \\
\text { of total }\end{array}$ \\
\hline \multicolumn{3}{|l|}{ Quantity discounts: } \\
\hline General & 20 & 17.5 \\
\hline $4-6$ percent on quantity orders & 32 & 28.1 \\
\hline $5-10$ percent on carlot or trailer lot & 10 & 8.8 \\
\hline 2 percent on quantity orders & 3 & 2.6 \\
\hline Reduced prices on 1,000 lots & 5 & 4.4 \\
\hline Reduced prices on $25,000-50,000$ lots & 1 & 0.9 \\
\hline Reduced prices on $10,000-25,000$ lots & 1 & 0.9 \\
\hline 5 percent on solid paper if annual purchase exceeds $\$ 5,000$ & 3 & 2.6 \\
\hline Subtotal & 75 & 65.8 \\
\hline \multicolumn{3}{|l|}{ Brokerage allowances: } \\
\hline General & 2 & 1.8 \\
\hline 5 percent & 16 & 14.0 \\
\hline 5 percent dealer's discount & 1 & 0.9 \\
\hline 5 percent distributor's discount & 1 & 0.9 \\
\hline Subtotal & 20 & 17.5 \\
\hline \multicolumn{3}{|l|}{ Warehouse storage allowances and early-season discounts: } \\
\hline Preseason discount-general & 2 & 1.8 \\
\hline 3 percent discount preseason delivery & 1 & 0.9 \\
\hline 10 percent discount on early-season purchases of box shook & 3 & 2.7 \\
\hline $\begin{array}{l}0.65 \text { percent storage allowance per month on cartons- } \\
\text { maximum of } 6 \text { months }\end{array}$ & 11 & 9.6 \\
\hline Subtotal & 17 & 14.9 \\
\hline \multicolumn{3}{|l|}{ Other allowances: } \\
\hline $1 / 2 \notin$ (about 1.5 percent) per crate if packer unloads & 1 & 0.9 \\
\hline Unused containers carried on supplier's inventory at no cost to packer & 1 & 0.9 \\
\hline Subtotal & 2 & 1.8 \\
\hline Total & 114 & 100.0 \\
\hline
\end{tabular}


Table 18.-Reasons for not taking quantity discounts brokerage allowances, and warehouse and other allowances on containers and packaging supplies where such allowances were available

\begin{tabular}{l|c|c}
\hline \multicolumn{1}{c|}{ Reason } & $\begin{array}{c}\text { Number } \\
\text { reporting }\end{array}$ & $\begin{array}{c}\text { Percent } \\
\text { of total }\end{array}$ \\
\hline $\begin{array}{l}\text { Do not buy in large enough } \\
\text { quantities }\end{array}$ & 12 & 42.8 \\
$\begin{array}{l}\text { Operation too small and } \\
\text { seasonal }\end{array}$ & 4 & 14.3 \\
$\begin{array}{l}\text { Insufficient warehouse space } \\
\text { Uncertainty of fresh fruit } \\
\text { crops }\end{array}$ & 7 & 25.0 \\
$\begin{array}{l}\text { Difficulty in anticipating } \\
\text { usage }\end{array}$ & 1 & 3.1 \\
$\begin{array}{l}\text { Growers too busy to haul } \\
\text { their own crates }\end{array}$ & 1 & 3.6 \\
$\begin{array}{l}\text { Manufacturer uses warehouse, } \\
\text { so no sense in bargaining } \\
\text { when we use a continual } \\
\text { supply }\end{array}$ & 1 & 3.6 \\
\hline $\begin{array}{l}\text { Total } \\
\text { nan }\end{array}$ & 28 & 100.0 \\
\hline
\end{tabular}

\section{Patronage Refunds Received}

A major source of savings to members of supply cooperatives furnishing containers and packaging materials is the patronage refund. This refund normally replaces any quantity discount or brokerage allowance to the local member, and ranges between 4 and 5.5 percent of the sales price.

Cooperative packinghouses belonging to regional supply cooperatives in specified States indicated the following annual rates of patronage refund received from their supply association in recent years: (1) Citrus packinghouses in California received patronage refunds averaging 4.7 percent; (2) deciduous fruit packers in California reported an average of 5.5 percent; (3) Florida citrus packers reported receiving patronage refunds at two widely different levels, either 2 percent or 10 percent, due to variations in the operations of the supply cooperatives involved; (4) Washington deciduous fruit packers received an average of 3.2 percent; and (5) in Maine, consolidated patronage returns to potato growers from their marketing-supply cooperative averaged approximately 4 percent on bags and various production supplies.

\section{COMPARISONS OF NET PRICES PAID}

Comparisons of prices paid for containers and packaging supplies purchased from cooperative supply associations and from private sources were difficult to make. Most packers purchasing through supply cooperatives bought their entire supply from this source and the complex discounts, patronage refunds, and other price factors had to be considered in arriving at net prices paid. However, sufficient data were developed to permit comparison of net prices paid for citrus containers, deciduous fruit containers, potato bags, and certain vegetable containers in 1963-64. Net prices and savings shown are based on prices after all discounts as indicated by packers' replies and after deducting patronage refunds made to members by cooperative supply associations.

In California, the net prices or costs of citrus cartons purchased through cooperatives averaged 4.4 percent less than for those purchased from private suppliers. In Florida, the costs of paperboard citrus cartons averaged 7.3 percent less and the savings on wirebound wooden boxes averaged from 8.3 to 16.9 percent less. Savings also were shown for other packaging materials.

In Washington, somewhat similar findings were reported for containers and packaging supplies for deciduous fruits purchased through cooperative supply associations. The savings from cooperative purchase ranged from 6.5 to 9.6 percent on apple cartons, 16 to 22 percent on wooden lug boxes, 5.9 to 8.7 percent on polyethylene products, and 5 percent on paper fruit wraps.

In Florida, savings through cooperative purchase of vegetable containers averaged approximately 4.6 percent.

In Maine, costs of paper bags purchased through cooperatives averaged 3.1 percent less than those from other sources. Net costs on 5-1b. poly bags and 10-lb. mesh bags were 8.3 and 10.4 percent less, respectively; but costs of $10-\mathrm{lb}$. poly bags, 100-1b. burlap bags, and wire ties were higher from cooperative sources. 


\section{EXISTING CONTAINER PURCHASING COOPERATIVES}

Possibilities of the cooperative purchase of containers and other packaging materials for fresh fruits and vegetables can be illustrated by a brief review of the activities of five container-supplying cooperatives and one large marketing cooperative that has a container and orchard supplies department. Also, the California Fruit Exchange, Sacramento, Calif., has a supply department that annually purchases about $\$ 3$ million worth of containers for 18 member associations and 350 grower-shippers.

\section{EXCHANGE SUPPLY AND SERVICE COOPERATIVE, TAMPA, FLA.}

The Exchange Supply and Service Cooperative is an affiliate of the Florida Citrus Exchange, Tampa, Fla., with the same board of directors serving each. It was organized in its present form in 1949, having formerly operated as the Exchange Supply Company, which was started in the 1920 's. It serves 42 member cooperative packinghouses and 8 private packing companies located throughout the citrus-producing areas of Florida. A bona fide member must purchase one share of common stock having a par value of $\$ 10$. This is the only investment required.

Exchange Supply purchases a variety of containers and packaging supplies for its member packinghouses; these items account for about 97 percent of its supply business. The other 3 percent consists of such items as ethylene gas, clippers, gloves, picking bags, paint, and soaps and cleaners. Corrugated paperboard cartons account for nearly two-thirds of the total volume, followed by wirebound crates, wooden field boxes, consumer bags, paper guards and pads, strapping, wire, nails, and labels. Wirebound boxes formerly were the major type, but have been decreasing in importance as Florida packers shift to corrugated paperboard cartons.

Total annual value of purchases through Exchange Supply normally ranges between $\$ 2.5$ million and $\$ 3.0$ million.

Exchange Supply operates strictly as a "dropshipment" supply brokerage firm. It neither owns nor leases any buildings or equipment other than office facilities in the Florida Citrus Exchange building in
Tampa. Two fieldmen work with members on their supply problems.

Members' orders are placed through Exchange Supply to manufacturers who deliver directly to the member packinghouse. Purchases of both paperboard containers and wirebound crates usually are made from companies that have warehouses in Florida. Billing is done by Exchange Supply on invoices to members. By concentrating orders with a relatively small number of suppliers, Exchange Supply is able to negotiate a favorable price on items purchased. Purchases are made continually on order from member packinghouses; most purchases are made during the packing season-October to May. Almost all purchases are in truckloads or rail carload lots.

All supplies are priced competitively to members on a uniform, delivered basis. Billing is monthly and a discount of $1 / 2$ to 2 percent (depending on the product) is allowed for prompt (10 days) payment. Arrangements are available for extending credit to members for up to 120 days.

Exchange Supply is normally allowed a brokerage fee or trade discount, or both, by the manufacturer. For example, on paperboard cartons a 5-percent discount is normally allowed on net container costs after deducting freight charges. This amount is retained by Exchange Supply and any balance over operating costs is refunded to members as a patronage refund. In the past, a brokerage fee and a discount have been allowed on wirebound crates, but in recent years the discounts have been discontinued and list prices reduced accordingly.

Gross revenue from such brokerage fees or discounts has varied from $\$ 100,000$ to $\$ 150,000$ annually. The net balance or saving after operating expenses has varied from $\$ 50,000$ to $\$ 75,000$, equal to 2 to 2.5 percent on members' purchases.

The principal sources of savings to member packinghouses are: (1) A favorable, negotiated price on containers and packaging materials; and (2) savings remaining from brokerage fees after deducting operating expenses. Benefits to members thus have been substantial, considering the extremely small initial investment required of each. 


\section{GLADES BROKERAGE COMPANY PAHOKEE, FLA.}

The Glades Brokerage Company, organized in 1952 , is a cooperative serving five vegetable packers in the Pahokee-Belle Glade area in Florida. Four of the member packers are cocperatives and one is a private firm. Glades Brokerage operates solely on a container supply brokerage basis. Due to its small membership, the organizational structure is simple-a representative of one member serving as president and another as secretary-treasurer. The organization owns no land, buildings, or equipment, and rents no offices or other facilities. No salesmen or field representatives are employed.

Members of Glades Brokerage pack several types of vegetables-mainly corn, snap beans, and celeryand therefore require a variety of container types and sizes. Other vegetables packed are cabbage, cauliflower, radishes, and endives. In addition to special crates for many products, general-purpose crates in sizes of $0.85,4 / 5,11 / 9$ and $13 / 5$ bushel are used. Most vegetables are field-packed by producers and as a result, deliveries of containers ordered through Glades Brokerage are made directly to the producer who is associated with one of the member packinghouses. Containers are provided without labels and members paste on their own brand labels.

The value of containers purchased by members through the company varies from $\$ 500,000$ to over $\$ 1$ million per year, depending on variations in members' business. Members normally buy most of their containers through Glades Brokerage, but can purchase independently when it is to their advantage.

Glades Brokerage Company negotiates with available container suppliers for the best net price for its members. This involves considerations of type and quality of containers offered, as well as list prices and discounts or brokerage fees. Normally purchases are concentrated with two or three major suppliers.

Discounts and brokerage fees earned represent the principal sources of savings to members of Glades Brokerage Company. Generally, a 2-percent discount is offered for prompt payment. In addition a 3- to 5-percent brokerage fee is normally available. Containers are priced on a delivered basis and nearly all orders are in full rail carload or truckload lots.
Suppliers bill Glades Brokerage and invoices are simply transferred to Glades' invoice forms for billing members. The members are billed at list price minus allowable discounts for prompt payment. Brokerage fees and trade discounts are held by Glades until the end of the season. Operating costs, which approximate $1 / 2$ of 1 percent of purchases, are deducted and the balance is returned to members as a patronage refund. Net savings in the last 5 years have ranged from $\$ 26,000$ to $\$ 49,000$ a year-equal to about 3.9 to 4.3 percent of members' purchases.

\section{NORTHWEST WHOLESALE, INC., WENATCHEE, WASH.}

Northwest Wholesale, Inc., is an integrated supply-marketing-processing cooperative serving deciduous fruit growers and packers in the Wenatchee-Okanogan district in Washington. It serves 55 members and approximately 60 nonmember patrons. The latter consist of both cooperatives and other packers. Northwest Wholesale handles a general line of supplies, but containers and packaging materials account for over 70 percent of the dollar value of its supply business.

The association started in 1937 but made little progress until 1941, when a credit program, through USDA and the Regional Agricultural Credit Corporation, enabled fruit growers in the area to re-establish their operations.

Demands for wooden boxes during World War II resulted in the purchase of a lumber milling company which was operated until 1954. It was sold to a private firm which now supplies wooden box materials required by Northwest Wholesale, Inc.

The transition to fiber boxes and bulk bins by the apple industry created a need for a local fiber box fabricating facility. Therefore, in 1956, Northwest Wholesale entered into a lease agreement with Western Kraft Corporation for establishing a fiber box "sheet plant" in Northwest's warehouse facilities in Wenatchee. This plant has been in operation since 1958. Northwest Wholesale erected a building $100 \mathrm{ft}$. by $220 \mathrm{ft}$. to house the container fabricating facilities and leased it and part of a warehouse to Western Kraft Corporation. Warehouse space also is leased to another container corporation. 
The agreement is a building lease and distribution contract relationship. Western Kraft has other distributing contracts from this plant, but sells a major part of its carton output, on contract, to Northwest Wholesale. Western Kraft limits its operation at Wenatchee to carton fabrication. Corrugated paperboard blanks are shipped from its corrugating plant at Beaverton, Oreg., to the Wenatchee plant where they are cut, scored, fabricated, and printed into cartons to specifications.

The principal containers and packaging supplies handled by Northwest Wholesale, Inc., include fiber apple boxes, which account for about 60 percent of container and supply sales; wooden boxes for pears and other soft fruits, which make up about 20 percent; and paper wraps, liners, polyethylene bags, and pulp trays, which account for the remaining 20 percent. Sales of these products approximates $\$ 2$ million annually.

Northwest Wholesale concentrates its purchases and negotiates prices with major suppliers. It normally contracts with three or four suppliers for fiber cartons, but obtains the largest quantity from the fabricating company with leasing arrangements. It contracts usually with two firms for polyethylene bags, two for pulp trays, and one each for paper wraps and wooden boxes. Leasing of warehouse space to two container companies makes it unnecessary for Northwest to carry an inventory of fiber cartons, but enables it to have prompt service and priority for needed items. It maintains a working inventory of wooden boxes and packing supplies valued at about $\$ 200,000$ at the peak of the season.

Most containers and packaging supplies are shipped from manufacturers to Northwest Wholesale or directly to members in full truckloads. About 80 percent of the truck shipments move in manufacturers' own trucks and 20 percent in common carrier trucks. About 60 percent of total shipments move directly from manufacturer to the members of Northwest.

Containers and other supplies are billed to patrons at prevailing prices in the area, and on the basis of a uniform delivered price. Discounts for prompt payment-usually 1 percent on cartons and 4 percent on wraps-are passed on to member packinghouses. No other discounts were reported. Where manufacturers granted storage allowances on containers or other packaging supplies, such savings were passed on to the member packinghouse if it provided the storage space. Such storage allowance was 0.65 percent per month for a maximum of 6 months, or 3.9 percent.

Northwest bills members on delivery, except that when delivery is made before September 1, billing is delayed until November 1.

Members are not required to purchase all of their containers and packaging supplies through Northwest Wholesale, Inc., and may buy from other sources when it is to their advantage to do so.

In the last 5 years, Northwest Wholesale's net savings on its container and other supply operations have ranged from $\$ 200,000$ to $\$ 300,000$ a year. These averaged from 3.8 to 5.5 percent on sales.

Over its history Northwest has realized total savings of $\$ 4,854,246$ of which about $\$ 3,871,514$ was paid in cash and $\$ 982,732$ was retained in the business.

\section{PURE GOLD, INC., REDLANDS, CALIF.}

The Supply Division of Pure Gold, Inc., Redlands, Calif.-a large marketing cooperative-serves 17 citrus packinghouses and 11 deciduous fruit and vegetable shippers in California and Arizona. The total annual purchases for members the last two seasons have been around \$2.5 million. It purchases citrus cartons and various types of shook for deciduous shipments as well as picking and storage box shook. It also purchases fertilizer and general packinghouse supplies.

A completely separate set of financial records are kept in the Supply Division and it is charged for rent, telephone, and the like so that it stands its full costs of doing business.

The relation of sales of fiberboard cartons to wooden box containers varies according to the relative size of the citrus and deciduous crops each year. In the 1966-67 season, when citrus volume was large and deciduous volume was small, about 90 percent of the Supply Division's total purchases were for containers and packing supplies. About 82 percent of this amount consisted of fiberboard cartons, 
about 12 percent picking and storage box shook, and about 6 percent shook for various deciduous containers.

In the 1965-66 season, about 94 percent of total purchases were for containers and packing supplies, with about 73 percent of this amount consisting of fiberboard cartons, about 2 percent picking and storage box shook, and about 25 percent shook for various deciduous containers.

Members' orders are placed with the Pure Gold Supply Division which in turn places the orders with the manufacturers or suppliers, and prepares purchase order confirmations for the supplier and the member shipper as a matter of record and as a basis for subsequent invoicing. Purchases are made for resale with the supplier invoicing the Pure Gold Supply Division which in turn invoices its members.

Generally a trade discount is allowed, after deducting freight from the delivered price, which is retained by Pure Gold Supply as its operating margin and referred to as a retain. If the purchase does not involve a discount, a markup is made to cover the operating margins.

Cash discounts are passed on to members if they pay invoices within the discount period. There also are arrangements for extending credit an additional 90 days through the use of trade acceptances. At the end of the fiscal year, all operating funds retained in excess of the departmental cost of doing business are returned to the members as a year-end patronage refund.

For the 1966-67 season, the average net operating margin (retain) on all members' invoices was 3 percent. This was refunded to the members and amounted to approximately $\$ 75,000$.

The principal savings are those brought about by lower volume prices and, through economical operation, the ability to pass these on to members.

\section{MICHIGAN CERTIFIED FARM MARKETS, LANSING, MICH.}

Michigan Certified Farm Markets (MCFM) is a nonprofit organization of roadside markets which sells fresh produce and other agricultural products to the consuming public. It is a division of the Michigan Agricultural Cooperative Marketing Association which is associated with the Michigan Farm Bureau. The primary objective of MCFM is to provide members with an official organization and to identify them to the public as quality markets. It has 35 members, who operate roadside markets. Each owns a share of common stock in MCFM and pays annual service dues in advance. Their sales of products range from $\$ 5,000$ to $\$ 100,000$ and total about $\$ 500,000$ a year.

Michigan Certified Farm Markets has no facilities or formal brokerage agreements for the handling of containers or other supplies. However, the association has a unique, informal procedure which enables its grower-members to purchase containers at a saving. At the general membership meeting of MCFM, representatives of two container suppliers meet with the growers and a pooled order for the estimated container needs of all interested members is placed with the supplier. This qualifies each grower for a substantial volume discount, and MCFM for a brokerage allowance. Manufacturers bill the growers directly and make delivery directly to them except for very small orders. Further orders can be made during the season at the same discount on 2 weeks' notice.

Prices and discounts for containers are negotiated prior to the general meeting of the MCFM board of directors on the basis of current market prices and expected volume of business. Growers then purchase at the negotiated price.

The two main types of containers purchased through MCFM have been all-purpose paper bags (ranging in size from $1 / 4$ peck to 1 peck and $1 / 2$ bushel) and plastic jugs ( $1 / 2$ and 1 gallon in size) used mainly for apple cider.

There were a few problems during the first year of operation. Members were not accustomed to using the uniform types and sizes of containers and found it difficult to anticipate their needs. As a result more reordering occurred. Also, one company salesman quit and failed to deliver orders to the company, thus causing a reorder and much dissatisfaction among members.

During the first year of operation MCFM members saved $\$ 2.13$ per 1,000 , or 5.4 percent, on paper bags 
having an average list price of $\$ 39.63$ a thousand. Members were able to buy plastic jugs for an average of $\$ 150.40$ per thousand in 10,000 lots compared with $\$ 170.40$ in 1,000 lots. This was a saving of $\$ 20$ per 1,000 , or 11.7 percent.

Discounts to growers have averaged 5 to 5.5 percent on paper bags, 10 to 12 percent on plastic jugs, and 9 to 15 percent on glass jugs. An additional 1-percent discount is allowed for prompt payment. MCFM receives a 2-percent brokerage allowance.

In addition to giving growers more bargaining power in price negotiations, they often received better service and were able to market their products in more uniform containers. The brokerage fees helped cover the general operating expenses of the association.

The success of MCFM in procuring containers indicates the opportunities that exist just in consolidating purchases of small, independent growerpackers to obtain volume discounts from container suppliers. It also indicates that this can be done within an existing marketing association instead of through the organization of a separate supply association.

\section{AGWAY INC., SYRACUSE, N. Y.}

Agway Inc., Syracuse, N.Y., handles the largest volume of farm production supplies of any cooperative in the United States. It also engages in extensive marketing, processing, and agricultural service operations.

Agway's Distribution Division sells containers and packaging materials through its store and local representative system as a convenience to individual farmers who pack their own fruits and vegetables. Volume handled in this manner brings in only $\$ 250,000$ a year.

Agway's expanding marketing service centrally controls the procurement of package materials required by its numerous produce packing operations and by the local grower organizations packing under contract with Agway.

The overall fresh fruit and vegetable package material volume amounts to approximately $\$ 2$ million a year. It includes bushel baskets, bean hampers, wirebound boxes, corrugated cartons, multiwall paper bags, poly bags, overwrap trays and film, burlap bags, berry cups and baskets, and crates. Handling of these containers is expected to grow along with the fruit marketing operations.

Except for the marketing operation, representatives of Agway-and other large regional farm supply cooperatives contacted during the study-showed little interest in expanding any container supply business they now have. They expressed the opinion that providing containers for fresh fruit and vegetable packers is a specialized operation which should be conducted by specialized supply cooperatives directly associated with this industry.

\section{EXISTING CONTAINER MANUFACTURING AND FABRICATING COOPERATIVES}

Three cooperatives were engaged in the manufacture or fabrication of containers for their member packinghouses. Two were each affiliated with a single large regional marketing association, and the other independently served a number of marketing associations in a major citrus-producing area.

\section{HIGHLAND CRATE COOPERATIVE, JACKSONVILLE, FLA.}

The Highland Crate Cooperative manufactures wirebound wooden crates and corrugated paperboard boxes for cooperatives marketing citrus, celery, and poultry. It was organized in 1918 and serves 17 cooperative and 3 private packers.

Members of Highland Crate Cooperative are required to sign a purchasing contract which requires: "... On or before the 15 th day of October of each and every year, Member will notify Association in writing of the minimum number of such boxes, crates or containers which Member will require and purchase hereunder for his, her or its own use during the ensuing year and upon failure of Member to so notify, the Association shall use the number of such 


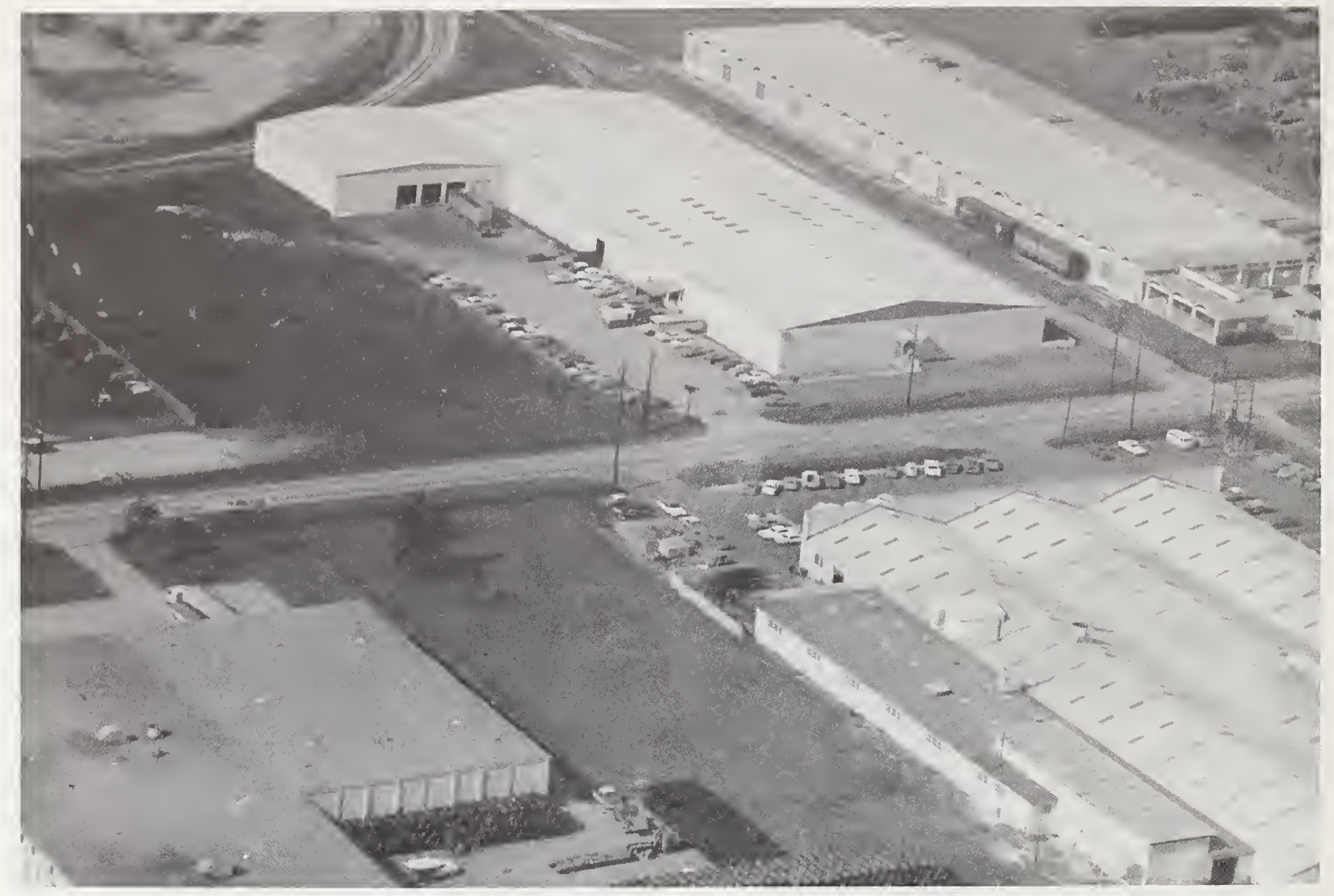

Partial view of Highland Crate Cooperative, Jacksonville, Fla.

boxes, crates or containers used by Member during the previous year as the number which Member is obligated to purchase hereunder for said ensuing year." The complete text of the purchasing contract is included in the appendix to this report.

Highland has been supplying between $\$ 4$ million and $\$ 5$ million worth of containers to members in recent years. Its volume in 1966-67 consisted of 967,466 $13 / 5$ bushel Bruce boxes; 4,286,504 0.85 bu. Bruce boxes; 453,130 4/5 bushel flats, 2,573,500 of 12-bird icepack poultry boxes, 5,493,970 citrus corrugated bc xes, and 741,750 miscellaneous boxes. This compares with a high volume year of 1961-62 when almost 2 million $13 / 5$ bushel boxes, 3.2 million 0.85 bushel boxes, and 270,000 4/5 bushel flats were sold.

There has been a rapid trend away from the use of $13 / 5$ bushel Bruce boxes to the half-size box $(0.85$ bu.). Use of the smaller box increased from 17 percent of sales from 1945-54 to 76 percent in fiscal 1963 and 83 percent in fiscal 1967.
Highland manufactures wirebound wooden boxes and corrugated paperboard containers. Its operations are completely integrated-from logging operations at St. Stephens, S.C., and the manufacture of veneer, lumber, and cleats at its South Carolina mills, to fabrication of completed crates and corrugated boxes at the Jacksonville, Fla., plant.

The cost or gross book value of land, buildings, and equipment for the veneer mill, cleat mill, and saw mill, at St. Stephen, S.C., is about $\$ 240,000$, and the cost of those at Jacksonville is about $\$ 350,000$. The latter includes a box mill, warehouse, office, motor equipment, and 5 box-making machines. Assets totaled about $\$ 1.6$ million and members' equity or net worth was $\$ 838,500$ at the end of 1967 . Patronage refunds payable totaled over $\$ 617,000$.

The cooperative normally manufactures 85 to 90 percent of the number of boxes bought by its members, and buys the remainder on the open market. This permits use of its plant and equipment as near to capacity as possible. 
A working inventory of veneer, cleats, wire, and other materials is maintained in the warehouse which is a part of the Jacksonville plant, but no appreciable inventory of finished boxes is maintained. Boxes are shipped to members without labels and members paste in their own house or brand labels.

No salesmen or full-time fieldmen are employed. The manager makes periodic trips to member packinghouses, and the Jacksonville office contacts members by phone weekly to get their requirements for the next week's use.

Almost all shipments of wirebound crates are made by rail in full carloads and cartons are delivered in by truck in trailer loads. All boxes are priced on a delivered basis. These prices are subject to discounts of 2 percent on wirebound boxes and 1 percent on cartons, and are further reduced by a patronage refund at the end of the year.

During 1945 through 1963, Highland's net savings on gross sales before the cash discount averaged 13.9 percent. Of this, 11.7 percent was refunded to members and 2.2 percent was held as an operating reserve. Thus members were able to obtain an 0.85 -bu. Bruce box with a delivered price of 30 cents for 25.8 cents before the cash discount and 25.2 cents after the discount.

Volume has increased substantially in recent years-from about $\$ 1$ million in 1964 to $\$ 4.6$ million in 1967. Net savings likewise increased from about
$\$ 111,200$ in 1964 to $\$ 702,500$ in 1967 . Since fiscal 1963 , net savings have averaged 14.8 percent of gross sales. They were 15.3 percent last year.

The citrus industry in Florida is using a greater percentage of corrugated, paperboard cartons each year. Highland realizes that if it is to service its members' requirements, it must manufacture paperboard cartons for citrus and diversify its wirebound wooden box manufacturing into other fields.

\section{FRUIT GROWERS SUPPLY COMPANY, LOS ANGELES, CALIF.}

The Fruit Growers Supply Company is a separate company but is affiliated with Sunkist Growers, Inc., Los Angeles and serves approximately 104 citrus packinghouse members. Seventy-six are cooperatives and 28 are agency firms. All directors of Fruit Growers Supply Company are also directors of Sunkist Growers and all members of Fruit Growers ship their fruit through Sunkist.

Fruit Growers Supply Company was established in 1907 and for over 40 years was a major producer and supplier of box shook used in the construction of the standard two-compartment wooden citrus box then in use. Substantial timber holdings were acquired in California and three mills were operated to produce these box materials; however, with the development of the paperboard citrus carton, the demand for wooden boxes disappeared and the

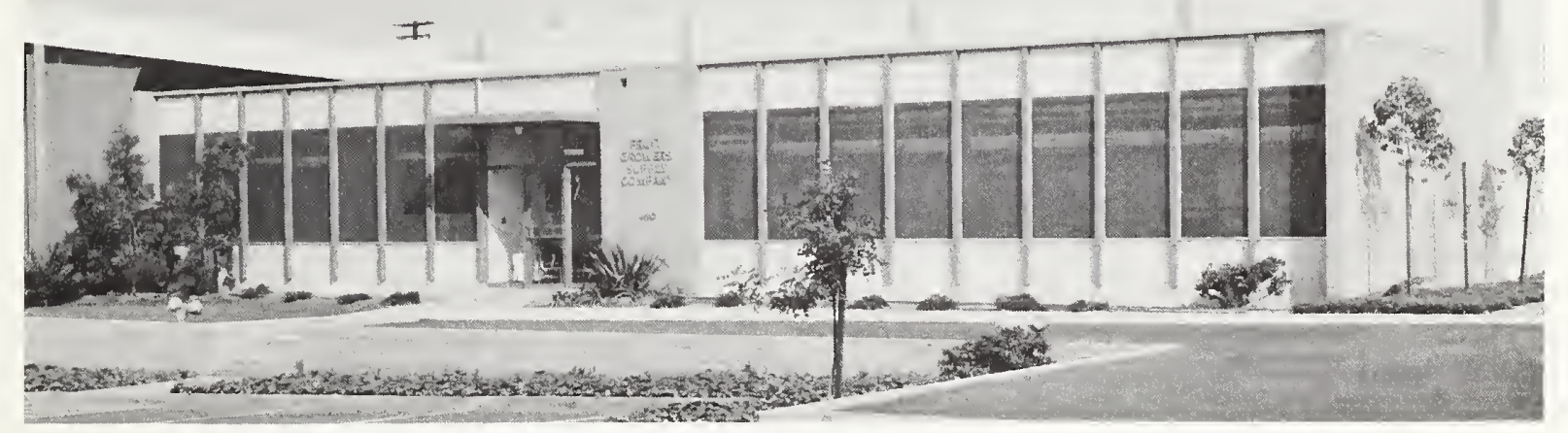

Office, plant, and portion of truck dock, Fruit Growers Supply Co., Los Angeles, Calif. 
timber and mill operations were shifted to the production of lumber for the commercial lumber market which is largely dependent on the building trade.

In 1961, Fruit Growers Supply Company entered into an agreement with Crown Zellerbach Paper Company, under which Crown Zellerbach supplies it with corrugated paperboard blanks suitable for fabricating citrus cartons.

A new, two-part container-manufacturing plant was built near Los Angeles. One part of the plant is owned by Crown Zellerbach and contains the corrugator and other equipment necessary to produce the corrugated paperboard blanks. The other part of the plant is owned by Fruit Growers Supply and contains equipment for printing and fabricating the blanks into completed citrus cartons. Crown Zellerbach operates Fruit Growers Supply Company's plant under a management contract. The two facilities are placed side-by-side and the paperboard carton blanks are transferred on a conveyor which takes palletloads through a connecting corridor from the Crown plant to the other plant for fabrication.

The size of Fruit Growers plant is $200 \mathrm{ft}$. x 320 $\mathrm{ft}$., and the cost of land, building, and equipment was about $\$ 1.2$ million.

Two types of paperboard blanks are produced for Fruit Growers-one with a light silver gray outerfacing for the top or outer portion of the two-piece telescope cartons; and one natural brown kraft paper outerfacing for the bottom or inner part of the carton. A picture of Fruit Growers' printer-slotter is on the cover of this report. This machine is being used as a printer only in the operation shown.

In fabricating cartons from the blanks, two processes are used for the top or outer part and a single process for the inner part. The blank is first printed with the Sunkist label plus the private brand of the packer. As the printed blanks leave the large, multicolor presses they move into the second machine which cuts and scores the carton pattern, diecuts ventilation or hand holes, and forms and glues the croton into the form in which it is received by the packinghouse. Finished cartons are then automatically stocked, palletized, and strapped with steel strapping for loading into railcars or trucks. Only a working inventory is maintained.
About 90 percent of Fruit Growers' containers and other supplies are delivered to members by trucks-either leased trucks or commercial lines.

Fruit Growers Supply Company supplies 55 to 65 million cartons $-\$ 14$ to $\$ 16$ million worth-to its member packinghouses each year. Approximately 70 percent of these cartons are fabricated in the Fruit Growers Supply Company plant and the balance is purchased from major container manufacturers in the area. This permits Fruit Growers Supply to operate its plant at near-capacity levels.

Fruit Growers maintains a quality control program to insure that all cartons, whether purchased or manufactured, meet the specifications of Sunkist's field department.

Fruit Growers handles six major types of cartons:

1. Standard carton for California oranges and lemons, and for Arizona oranges, lemons, and grapefruit.

\section{Standard carton for California grapefruit.}

3. California container for intrastate shipments of oranges and lemons.

4. California container for intrastate shipment of grapefruit.

5. Standard container for California and Arizona tangerines.

\section{Master container for poly bags.}

These containers have a base price per thousand, unventilated with standard one- or two-color, fourpanel printing, except for the master for poly bags which has only one color printing. Added charges (upcharges) are made for standard 12-hole ventilation, special 16-hole ventilation, vent holes in side panels, and handholds. Extra printings (press runs) are made for three or four colors.

Freight is prepaid on full carload (or two truckload) lots and all cartons are priced on a uniform, delivered basis to all member packers. Less-thancarload lots are priced f.o.b. sellers' plant with lowest carload freight rate allowed to destination. 


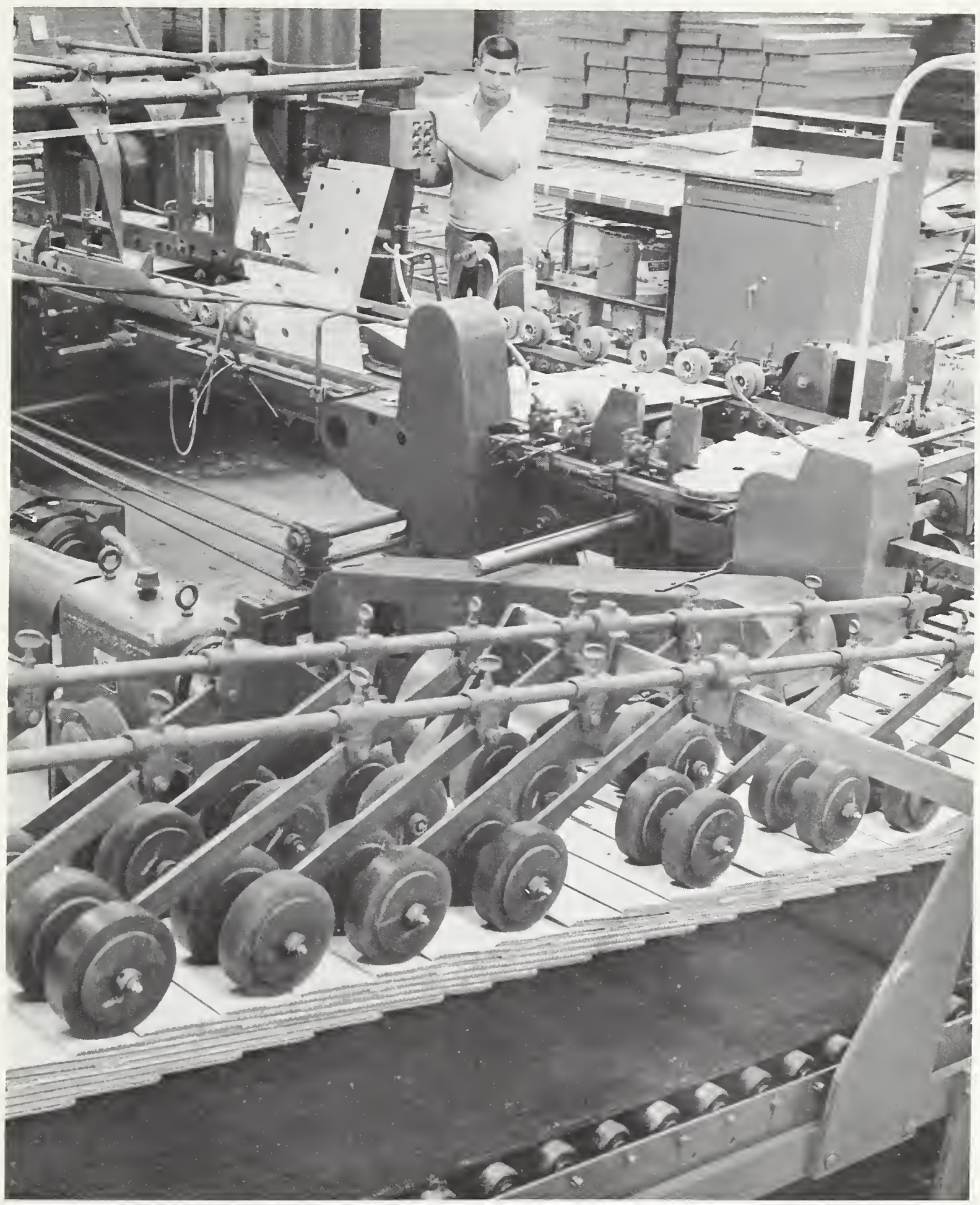

A folder-gluer joins sheets, glues tab, and forms box in Fruit Growers Supply Co. plant. 


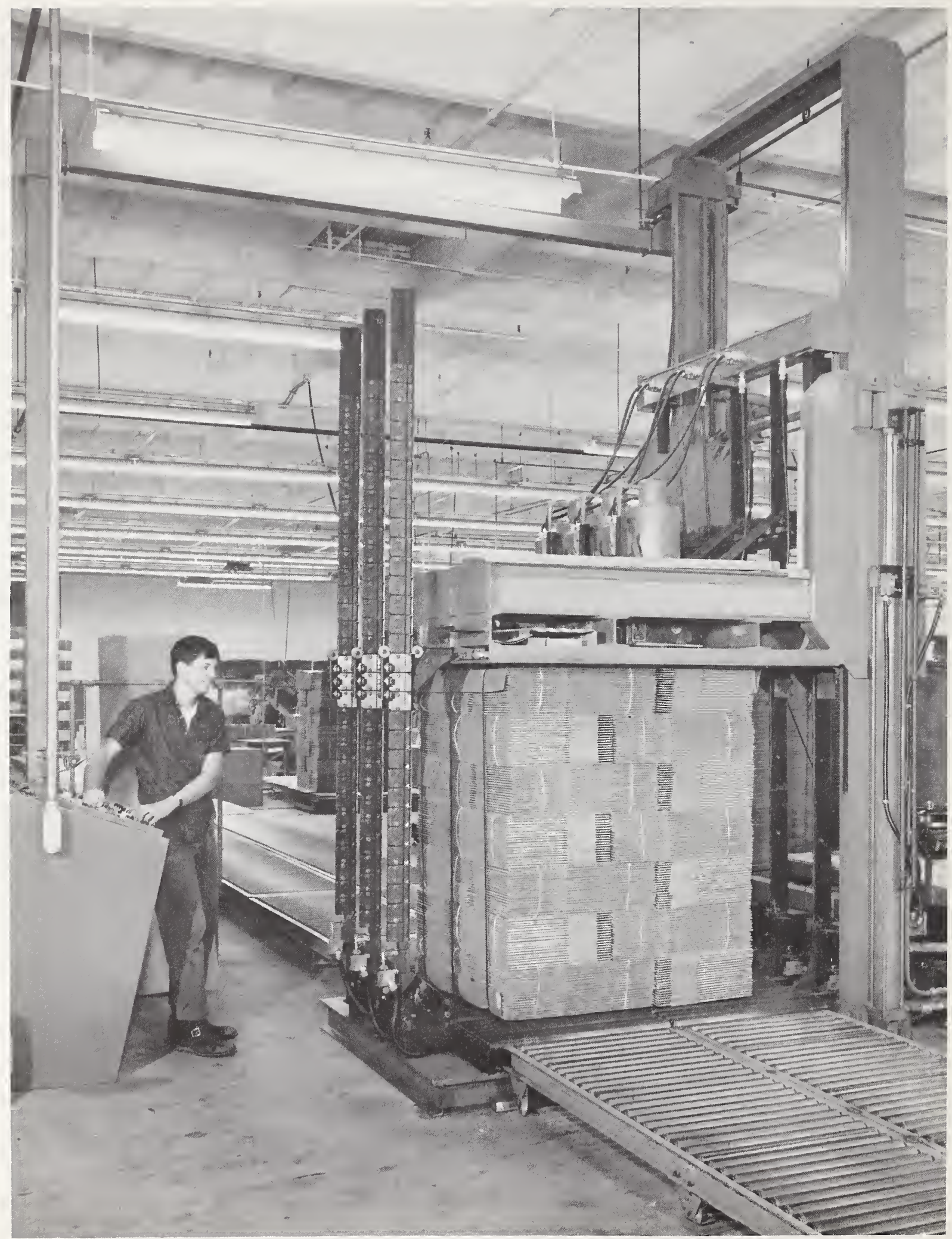

Strapping bottom halves of cartons in Fruit Growers Supply Co. plant. 


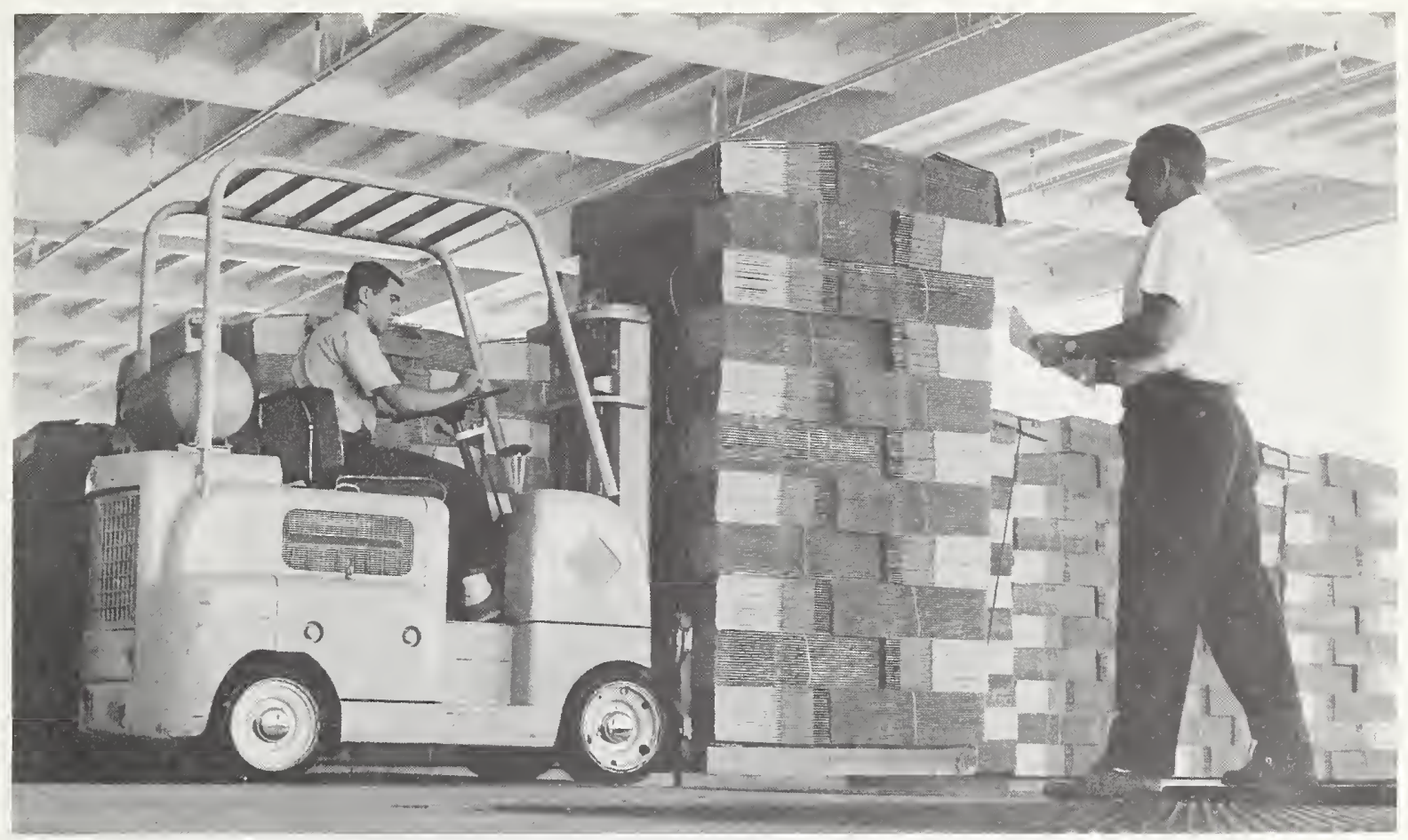

Forklift transports finished carton tops to truck loading dock, Fruit Growers Supply Co.

The minimum quantity for each print is 5,000 , except for the poly bag master which is 500 . A press set-up charge is made for orders of less than 5,000 .

In addition to paperboard citrus cartons, Fruit Growers Supply purchases for its members polyethylene bags, wooden field boxes and lemon storage boxes, biphenyl carton liners to inhibit molds, adhesives, other miscellaneous packaging supplies, fertilizers, insecticides, and miscellaneous grower supplies. These items, valued at about $\$ 5$ million annually, are purchased from outside suppliers and handled on a brokerage basis by Fruit Growers Supply Company.

Container purchases from outside suppliers are delivered as drop shipments directly to member packinghouses and normally are in full railcar or truckload lots. Thus Fruit Growers needs to carry very little inventory of such containers or packaging supplies.

Purchases of cartons by Fruit Growers Supply Company from outside suppliers are normally subject to trade and cash discounts, plus a brokerage allowance. Trade or volume discounts average approxi- mately 5 to 6 percent, cash discounts (10 days) 1 percent, and brokerage fees 5 percent, for a total possible discount off list price of 11 to 12 percent.

With the exception of small-lot sales, all cartons and other packaging supplies are sold at a uniform, delivered price, regardless of the location of the member packinghouse. Members are billed monthly for containers on the basis of prevailing list prices in the trade. Other supplies are billed at cost plus reasonable margins. Credit extension up to 90 days is at the current prime rate on funds that Fruit Growers may borrow.

The principal saving to members of Fruit Growers Supply Company is reflected in the patronage refund paid each year. Through the fabricating operations, trade discounts, and brokerage fees earned on items purchased, patronage refunds to members have averaged 8 to 13 percent on gross sales during the last 5 years. $^{3}$

\footnotetext{
${ }^{3}$ An additional and appreciable advantage is the dividend from earnings on the company's commercial timber operations.
} 
Although the container industry in Southern California is reported to be very competitive, members thus receive appreciable savings compared to buying containers individually in the open market. In addition, the fabricating operations of Fruit Growers assures them a supply of uniform high-quality containers and keeps them in close touch with the fabricating and corrugating phases of the container industry.

\section{MAINE BAG COMPANY, CARIBOU, MAINE}

The Maine Bag Company is owned and operated as a division of Presque Isle Growers, Inc., the Caribou Growers, Inc., and other cooperatives, private growers, and independent packers in the area. It is the only farmer-owned cooperative bag manufacturing plant in the United States.

In 1945, Maine Potato Growers purchased the burlap bag manufacturing plant of the Maine Potato Bag Co. in Caribou. Since then, Maine Bag has steadily increased its volume of operations and has expanded its product line. It now offers a full line of paper potato bags-from the 5-pound consumer package to a 50-pound multiwall bag-as well as burlap bags, mesh bags, polyethylene bags, and sewn and pasted multiwall bags for fertilizer, starch, and other items. It also handles wire ties, carlining paper, and miscellaneous supplies.

In 1950, Maine Bag began manufacturing wire ties and in 1953 started manufacturing and printing 5-, 10 -, and 15-pound paper potato bags. Manufacture of 25-pound and 50-pound baler bags was begun in 1956, and in 1960 manufacture of sewn and pasted multiwall bags was started. In 1965, the company began manufacture of cotton mesh bags and paste used in bag-making. It purchases polyethylene bags directly from manufacturers.

Paper potato bags account for approximately 75 percent of the total sales of containers and packaging supplies of Maine Bag Company and burlap bags account for another 20 percent. Other types of bags and packaging items account for the remaining 5 percent. It manufactures 90 to 93 percent of all containers and packaging materials it sells. The company estimates it supplies over 50 percent of the potato bags used in Aroostook County.
The Maine Bag Company has a total investment in land, buildings, and equipment, based on original cost of about $\$ 829,000$. Buildings account for $\$ 364,000$; machinery for $\$ 412,000$; trucks for $\$ 32,000$; and office equipment for $\$ 14,000$. The book or depreciated value of all facilities and equipment was about $\$ 372,000$ at the end of its 1967 fiscal year.

The Company's manufacturing operations are located at two different sites. At the Broadway Street location is a wooden frame building $380 \times 50 \mathrm{ft}$.; the main office is on the second story. The center portion, above $50 \times 150 \mathrm{ft}$., houses the burlap bag manufacturing operation. Here the baled burlap is unwrapped, rolled into large rolls, and then cut, printed, folded, and sewn into bags. Another machine turns the sewn bags so that the seams are on the inside.

The large $100 \times 50 \mathrm{ft}$.warehouse located on the end of the building is used for storing burlap prior to bag manufacture and for general storage. The small burlap storage area $(40 \times 50 \mathrm{ft}$.) on the other side of the manufacturing section is used for the storage of finished bags.

An area $40 \times 90 \mathrm{ft}$. at the other end of the building houses a hand-fed printing press and also a machine for manufacturing 5- and 10-pound mesh potato bags. Also located in the building is a hydraulic electric-heated press which is used to make molded rubber printing plates. It is large enough to make a complete plate for the company's largest multiwall bags. Wire ties also are manufactured at the Broadway Street location.

At the Sincock Street location is a wooden frame one-story building, $610 \times 50 \mathrm{ft}$. A center section, 160 $x 50 \mathrm{ft}$., houses the two paper bag machines, which cut the rolled paper to size and fold, paste, print, and count the bags of various sizes as they are produced. The large machine also manufactures the large multiwall (up to five plies), sewn and pasted bags.

In one end of the building is a large $340 \times 50 \mathrm{ft}$. finished goods warehouse, and in the other end is a 110 x $50 \mathrm{ft}$. warehouse for rolled paper (raw materials).

Recently another warehouse, $188 \times 30 \mathrm{ft}$., was constructed along one side of the finished goods warehouse. It is used to store finished paper potato bags. 

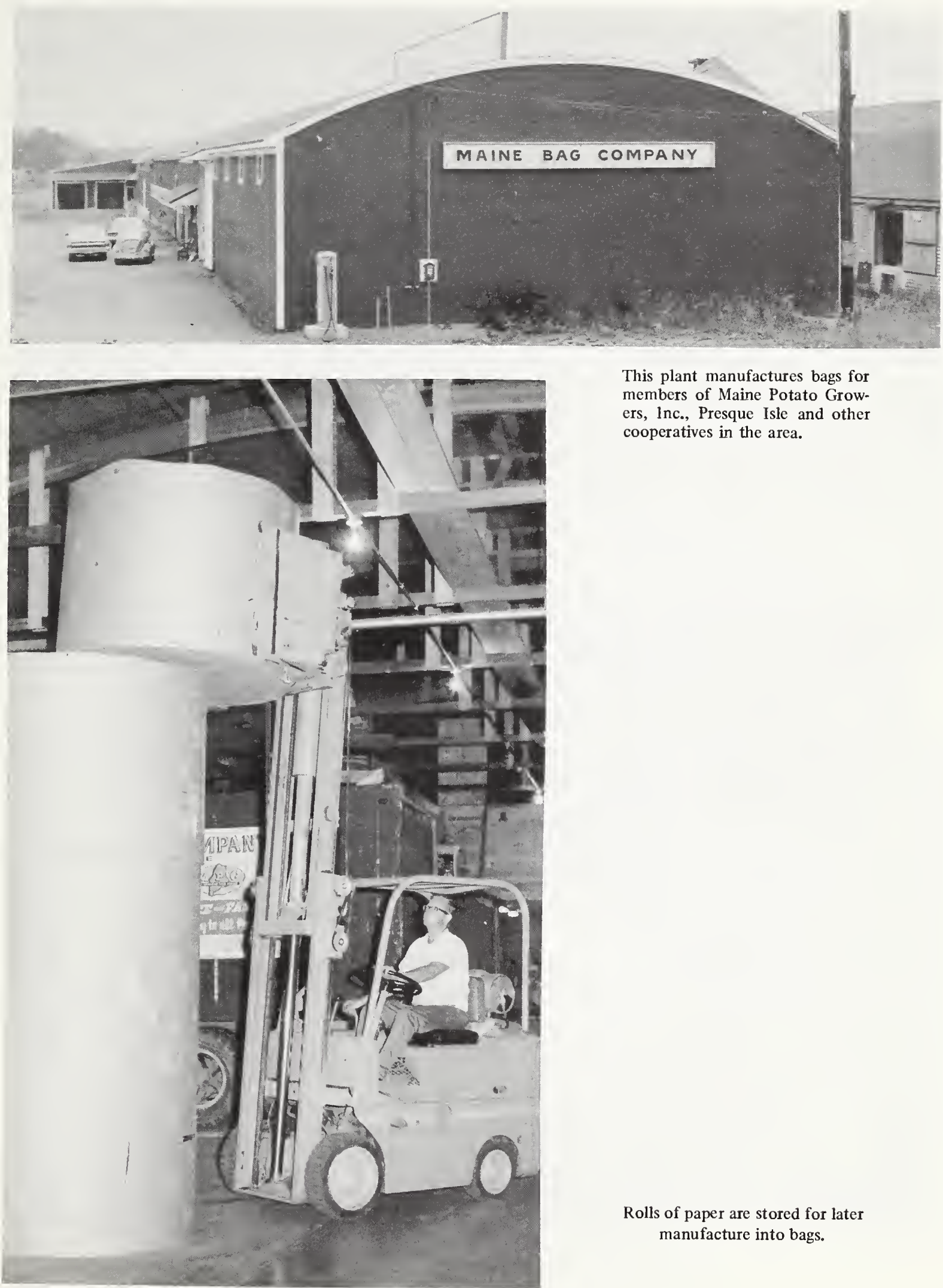

This plant manufactures bags for members of Maine Potato Growers, Inc., Presque Isle and other cooperatives in the area.

Rolls of paper are stored for later manufacture into bags. 


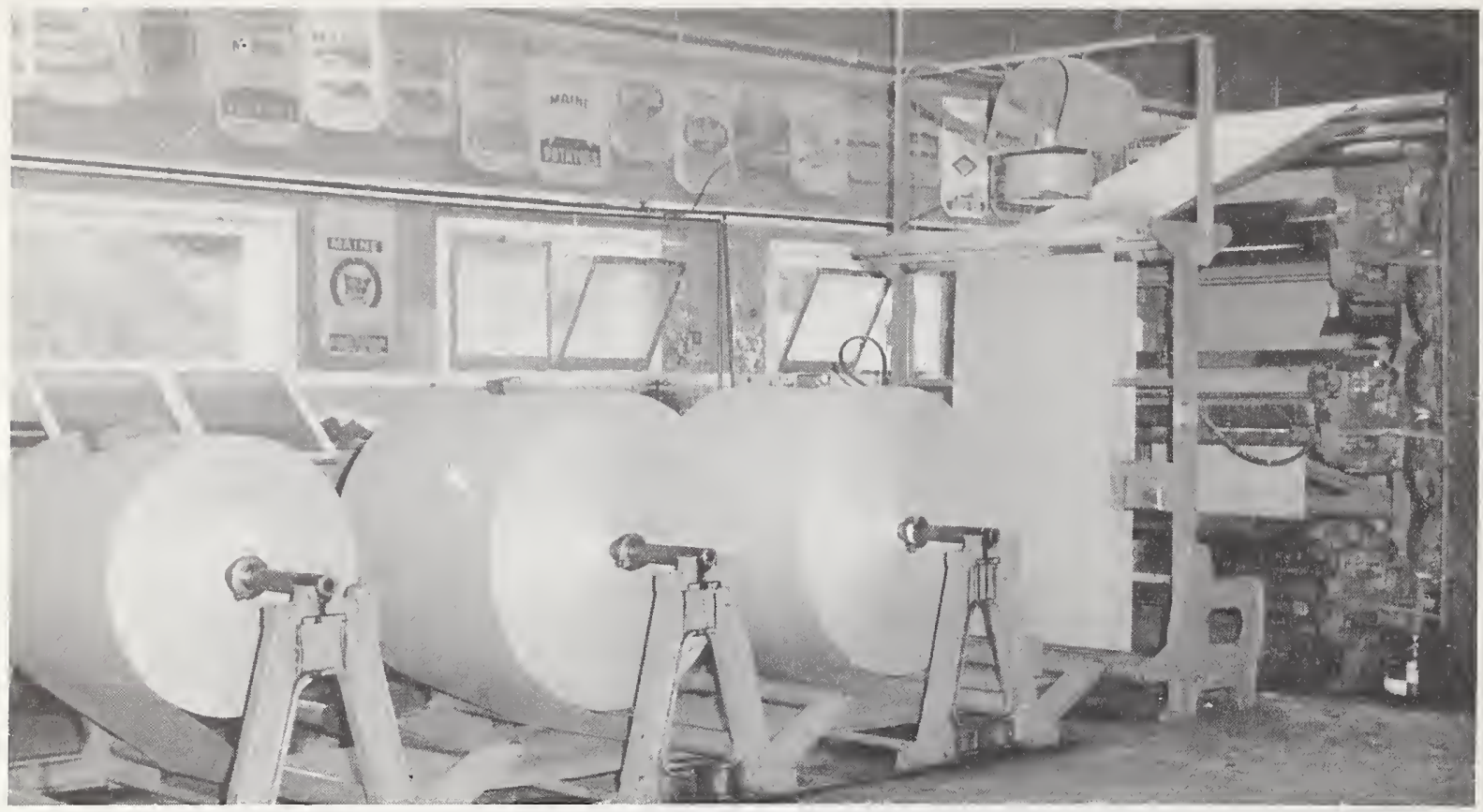

Paper is placed on spindles at start of the bag-making process.

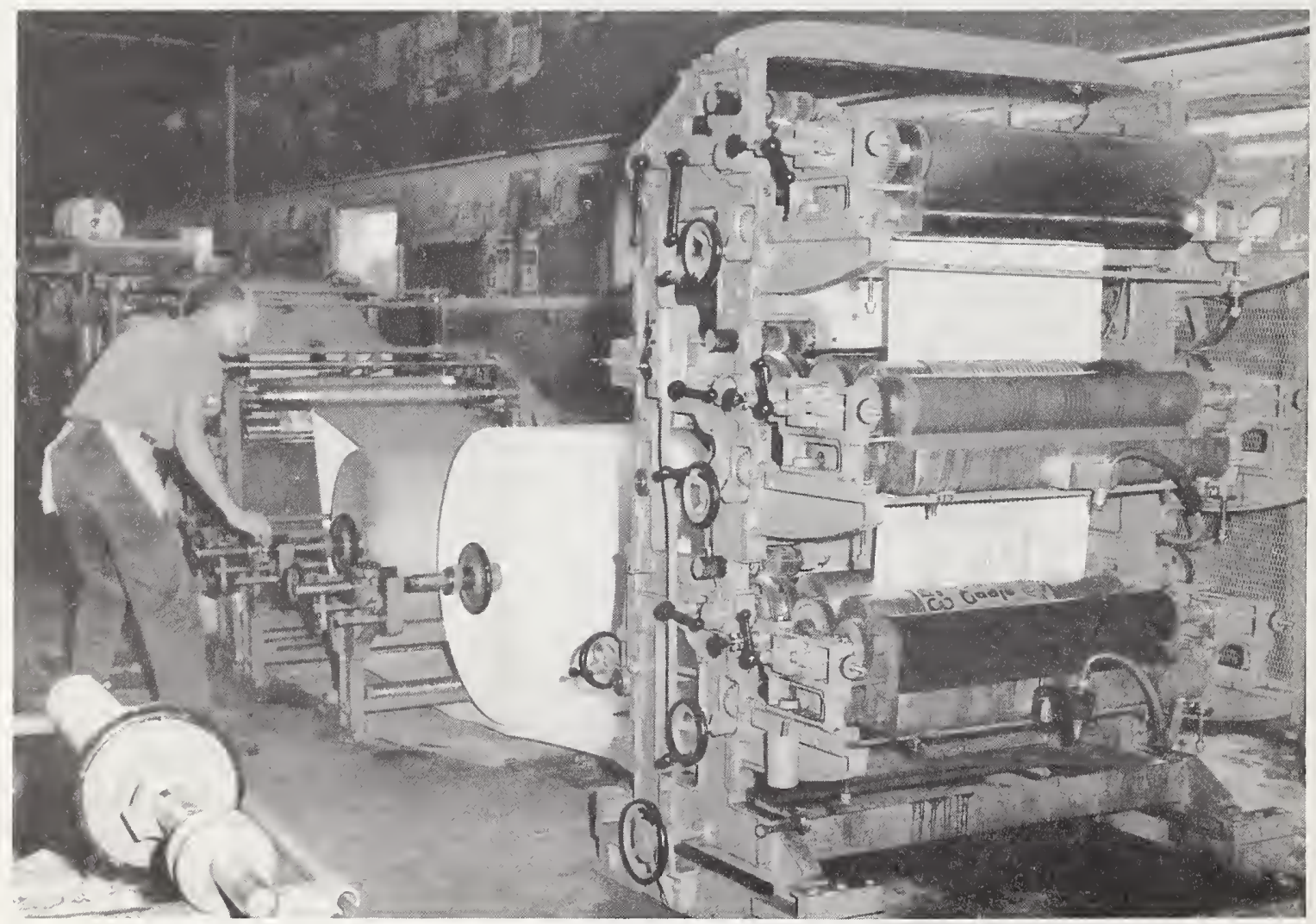

Paper is printed before being converted into bags. 


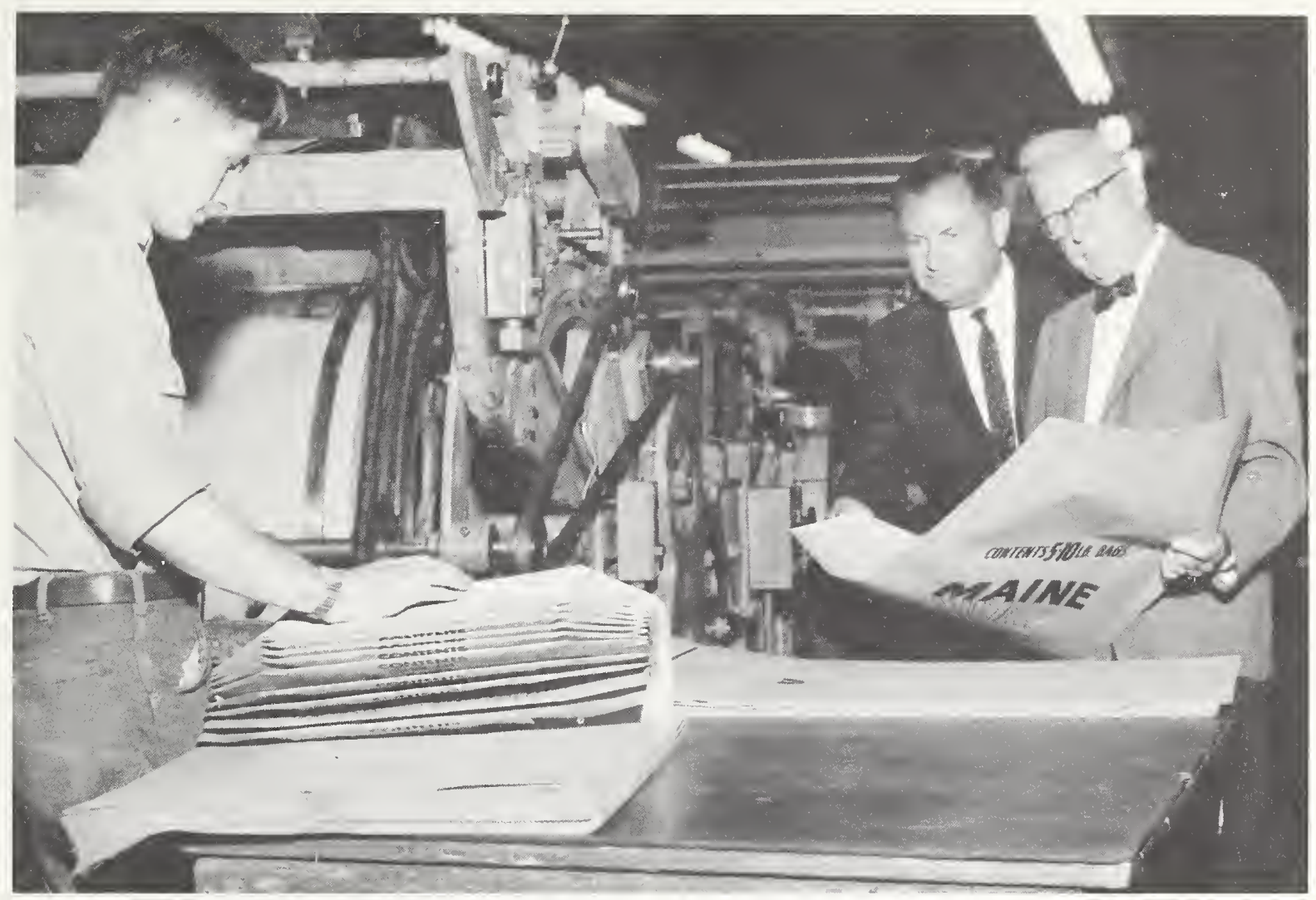

Herbert N. Aldrich, center, present manager, and Ralph W. Allen, right, first manager of the co-op's plant, checking finished bags.

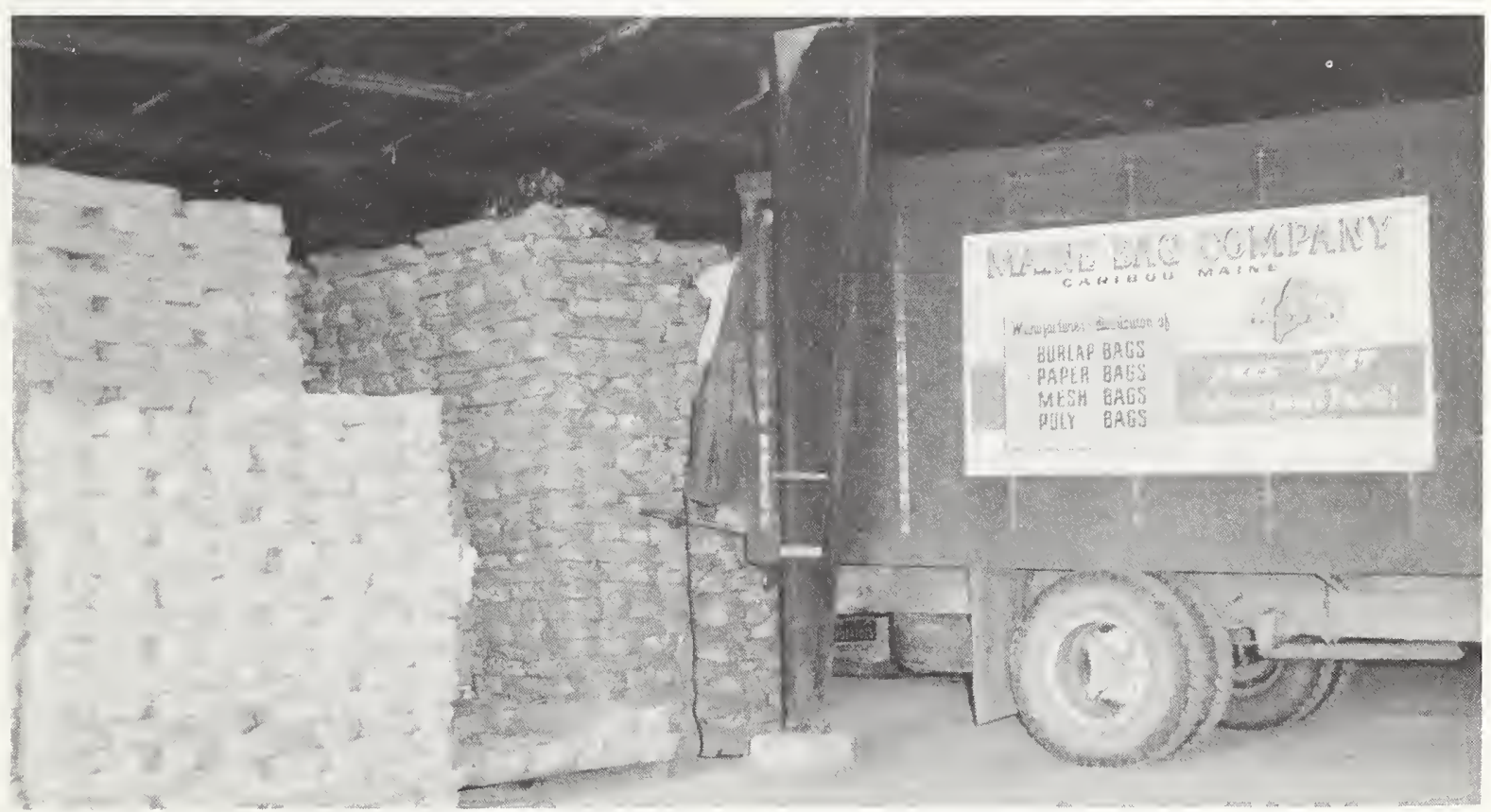

New bags are stored in warehouse, awaiting members' delivery order. 
The company operates a fleet of nine delivery trucks to supply patrons. Nearly all deliveries are made within 100 miles of the plant.

Thirty-five employees are employed the year round and an additional 50 are employed during the peak season.

Maine Bag uses approximately 4,000 tons of raw paper and 3 million yards of burlap a year in its manufacturing processes. Ninty-nine percent of the raw paper is purchased from firms in the Southeastern United States. Orders are placed approximately every 10 days at current open market prices, and the raw paper is transported by rail.

Burlap is imported from Calcutta, India, through two importers. Time and frequency of purchases vary depending on open market prices. Ample storage facilities at Maine Bag allow considerable flexibility in purchasing burlap and "stocking up" in periods of lower prices. Approximately 100 percent of the burlap is transported to the plant from warehouses in Boston or New York by Maine Potato Growers' trucks on their return trips from making southern deliveries of potatoes.

All purchases of raw paper and burlap are made at open market prices and no discount or special pricing arrangements exist.

The Maine Bag Company employs one salesman to handle its sales program. All bags are sold on the basis of delivered prices, which are competitive with other suppliers in the area.

Almost all of the patrons interviewed in the area reported that they received superior service from Maine Bag. Normally, a packer can order bags early in the morning and receive delivery that same day. If the bags do not have to be printed, the delivery is almost immediate.

Maine Bag also keeps a full line of printing plates on hand, or is able to design and make the plates for an individual customer in a very short time. This enables each patron to have his own custom brand if he so desires.

Customers are billed for their purchases upon delivery and receive a 1-percent discount if they pay cash within 10 days.

Annual sales of Maine Bag in the last 5 years have ranged from $\$ 2.3$ million to $\$ 2.5$ million. This includes over 40 million bags a year. Total manufacturing and general administration expenses have ranged from 13 to 14 percent of sales.

Net margins of Maine Bag Company have ranged from 11 to 14 percent of sales in the last 5 years. Such savings, however, are consolidated with those of other supply and equipment divisions of Maine Potato Growers, so this has resulted in a single but somewhat lower rate of patronage refund paid on total purchases by members.

\section{FURTHER OPPORTUNITIES FOR COOPERATIVE PROCUREMENT OF CONTAINERS}

The greatest opportunity for cooperative procurement (purchase or manufacture) of containers and packaging materials for fresh fruit and vegetable packers appears to exist in areas where a concentration of production is marketed through large regional marketing cooperatives. This is the situation in Florida, California, Washington, and Maine where affiliated container supply cooperatives or supply departments of marketing associations are successfully operating.

\section{COOPERATIVE PURCHASE}

Although the existence of a parent regional marketing association facilitates the organization and operation of a cooperative container supply function, it is not a necessity. Glades Brokerage Company in Florida is an example of a small group of packers operating independently who have organized to purchase cooperatively containers and other packaging materials. 
In general, the widest opportunities for cooperative purchase of containers and packaging materials appear to be in simple brokerage operations where the supply cooperative does not take title to the containers or other materials purchased, but simply consolidates orders from member-packers, negotiates with manufacturers for the best price, and invoices members for supplies they have ordered. No warehousing or physical handling of supplies is involved since manufacturers ship directly to the member's packinghouse. Such simple brokerage operations can be effectively operated without major staff, capital, and facility requirements and can utilize part-time help if this is all that is required.

Although it might be assumed that container supply could logically be one function of regional farm production supply cooperatives, those contacted during the study had little interest in handling containers and packaging supplies for cooperative fruit and vegetable packers. Insofar as they did handle containers, this business was limited in scale and offered only as a convenience to individual fruit or vegetable grower-shippers.

\section{COOPERATIVE FABRICATION OR MANUFACTURE}

Opportunities for cooperative manufacture of containers and packaging supplies are limited to situations where a large volume of a few types of standard containers are required. Good examples are seen in the container fabrication operations of the Fruit Growers Supply Company and the Maine Bag Company.

Trends in container use continue toward paper, paperboard, and plastic, and away from wooden containers and textile bags. These trends tend to limit cooperative container manufacture to fabrication rather than to the production of basic raw materials. The manufacture of both paper and plastics is characterized by high fixed costs of equipment needed for economies of scale, and domination by a limited number of very large corporations in both industries. On the other hand, equipment for manufacture of bags or cartons is less expensive, manufacturing processes are relatively simple, and there is no problem in purchasing basic raw materials (paper, paperboard, or plastics) from primary manufacturers.

\section{REGIONAL ANALYSIS}

Six major producing areas-California; Florida; Washington and Oregon; Maine; Eastern States (New Jersey, New York, and Pennsylvania); and North Central States (Ohio and Michigan)-all have concentrations of fruit or vegetable production and packing operations necessary to the operation of a containersupply cooperative. Brief comments on possibilities for further cooperative procurement of containers in each region and in other States follow.

\section{California}

Opportunities for increased cooperative purchase or manufacture of containers and packaging materials in California seem to be conditioned by the following factors:

1. The principal citrus and deciduous fruit industries of California are already served by cooperative container supply sources. Included among such cooperative supply organizations are The Fruit Growers Supply Company, affiliated with Sunkist, the supply department of Pure Gold, Inc., Redlands, Calif., which handles citrus containers, and the supply department of the California Fruit Exchange, Sacramento, which handles containers for deciduous fruits. These are all very large cooperatives which have been able to gear their container supply operations to benefit their member-packers.

2. Substantial opportunities, however, still exist for expansion of cooperative container procurement in California.

a. California produces nearly one-third of the tonnage of commercial fresh vegetables produced in the United States, packing nearly 50 million cartons of lettuce alone. Further, such vegetable production is concentrated in specialized areas. For example, artichokes near Watsonville, lettuce at Salinas, El Centro, and Santa Maria, and other produce concentrated in other localities. Many of the products are shipped in specialized containers (e.g., lettuce cartons) which are required in large numbers. These conditions favor cooperative container procurement. In the case of lettuce, the volume appears large enough to consider cooperative carton fabrication. 
3. In addition to major vegetable crops in California, there are a number of specialty cropsfigs, grapes, and strawberries-produced in volume and concentrated in localized areas where opportunities appear to exist for cooperative purchase of containers and other packaging materials.

4. Competition in the container supply industry in California is intense. Nearly all major container manufacturers have plants or distribution points in major fruit and vegetable producing areas and can provide good service and a full line of container types. However, partly because of this competition, opportunities for price and discount negotiations in the procurement of containers, through cooperatives, may exist.

\section{Washington and Oregon}

Washington and Oregon are major areas for producing deciduous fruit such as apples, pears, plums, and small fruits and berries.

Cooperative purchase of containers for apples and pears is well established through Northwest Wholesale, Inc. Expansion of this activity to packers not presently associated with Northwest Wholesale would seem to offer good potential. This area has a substantial number of specialized fruit and berry packing cooperatives and cooperative container procurement would seem logical.

\section{Florida}

The situation in Florida is similar in many respects to that existing in California. Citrus, the major fresh fruit crop, has available cooperative sources of containers and other packaging materials. Included are the Exchange Service and Supply Cooperative, affiliated with the Florida Citrus Exchange, which provides a container purchasing service; Highland Crate Cooperative which provides complete manufacture of wirebound wooden crates; and Glades Brokerage Company-a simple brokerage operation.

Due to a decline in the use of wirebound wooden boxes for citrus packing, the Highland Crate Cooperative might consider broadening its membership beyond the citrus industry and also fabricating paperboard cartons.
An opportunity appears to exist for the cooperative purchase of containers by the Florida winter tomato industry. Production of winter tomatoes is concentrated near Sarasota and in southern Florida near Homewood. Each of these areas produces a large volume for fresh pack, using a limited number of types of standardized containers. These two conditions, localized areas of production and standardized containers, are conducive to a concentration of bargaining power by a specialized container brokerage cooperative.

Major national manufacturers, however, have plants and regional distribution warehouses located in major fruit and vegetable production areas throughout the State, and provide excellent service on delivery and inventory maintenance.

Another opportunity for co-op purchase may exist in areas where there is a concentrated production of diversified fruits or vegetables. Simple container brokerage arrangements may be established which could result in an association getting a brokerage fee of approximately 5 percent.

\section{Maine}

Potatoes are the principal vegetable crop packed in Maine. Aroostook County is one of the most important potato-producing areas in the United States. Maine Bag Company supplies nearly all of the bags used by potato packing cooperatives in the area and has approximately 40 percent of the total potato bag market in Aroostook County.

It appears that Maine Bag Company will continue to supply the needs of its members, but will not have many opportunities for growth unless the marketing cooperatives increase their volume or unless it seeks nonmember business.

\section{Eastern States}

New York, New Jersey, and Pennsylvania produce and market substantial quantities of fresh fruits and vegetables, but cooperatives are few in this area. There are no major regional fresh fruit or vegetable marketing cooperatives in the area.

Two possibilities, however, may exist for cooperative procurement of containers and packaging supplies. One opportunity would be for regional farm 
supply cooperatives to handle containers and packaging supplies for both individual growershippers and for specialized fruit or vegetable marketing cooperatives. Agway Inc., handles limited numbers of fruit and vegetable containers for its grower-members. It seems possible that Agway might be able to supply several specialized fruit and vegetable packing cooperatives in the area with containers and other packaging materials on a more favorable basis than they are now buying them independently.

A second opportunity may exist in areas where there is a concentration of fruit or vegetable production. Examples include the mushroom section in eastern Pennsylvania, and vegetable production areas in New Jersey. In these areas, simple container supply brokerage cooperatives may produce worthwhile savings to member grower-shippers or packers.

\section{North Central States}

Michigan and Ohio offer many of the same problems and possibilities found in the East. There is virtually no organized cooperative container supply activity in this area and general farm supply cooperatives have not been interested in procuring containers for fruit or vegetable packers. An exception was found in Michigan Certified Farm Markets which supplies a limited volume of containers to roadside markets in Michigan.
Areas of concentrated production exist in each State and appear to offer sufficient volume and opportunities for cooperative procurement of containers. These include the red cherry production area in Michigan, vegetable production areas in southeast Michigan, hothouse vegetable areas in northern Ohio, and potato areas in Minnesota and the Dakotas. Each of these States is served by one or more regional farm supply cooperative, which could provide a container purchasing service if sufficient interest developed for it.

\section{Other States}

Other States have areas of concentrated fruit or vegetable production where cooperative purchase of containers would appear to offer possibilities.

Areas in the lower Rio Grande Valley of Texas have sufficient concentration of both citrus and winter vegetables to permit container supply brokerage cooperatives. The same would be true in the strawberry areas of Louisiana, peach areas in Georgia and Colorado, and concentrated production areas for potatoes, apples, and other deciduous fruits in several States.

Regional farm supply cooperatives are headquartered in Georgia, Alabama, Tennessee, Mississippi, Arkansas, Missouri, Iowa, Indiana, and other States. Many of them might provide a worthwhile container purchasing service to grower-shippers and local marketing cooperatives if requested.

\section{SUGGESTIONS}

Based on the experiences of fresh fruit and vegetable marketing associations in cooperatively procuring their containers and other packaging supplies, the following suggestions are offered to others who may wish to consider cooperative purchasing or carton fabrication.

\section{GENERAL}

1. Enlist the sponsorship and assistance of specialized regional marketing associations.
2. Organize a container purchasing cooperative among members (local marketing cooperatives and grower-shippers) with large concentrated volumes of a few products-preferably those which require only a few types of standardized containers.

3. Plan for members to provide the necessary capital in proportion to their container requirements.

4. Obtain self-renewing contracts with members whereby they agree to purchase at least 90 percent of their requirements through the container supply cooperative. 
5. Initially price containers and other supplies at competitive market prices. Budget for net margins or savings, above operating expenses, to be distributed as patronage refunds at the end of the year.

\section{PURCHASING CONTAINERS}

1. Begin operations on a simple brokerage basis. Perform necessary functions of price negotiations, ordering for members, and collecting from members. The cooperative need not buy items for its own account, maintain inventories, or assume responsibility for accounts of its members.

2. Develop specific container standards and specifications, including delivery and credit terms, for use in contract negotiations.

3. Consider service and quality as well as quantity and trade discounts and brokerage fees in purchasing containers and other supplies.

4. Contract with a limited number of manufacturers or suppliers for firm prices for containers required throughout an entire packing season.

5. Have drop shipments made directly from manufacturer or supplier to the local member packinghouses or marketing associations.
6. The manager or fieldman should visit memberpackers to assist them with their container procurement problems.

7. After getting the cooperative well established, offer services to other packing firms that use similar kinds of containers. Still later, purchasing services may be offered to other cooperatives or firms such as those using multiwall paper bags for fertilizers or feeds, or wirebound wooden boxes for broilers.

\section{FABRICATING CARTONS}

1. Initially limit operations to simple forming and printing of paperboard cartons which members use in greatest volume.

2. Purchase precut and scored paperboard carton blanks from major paperboard manufacturers on an annual, negotiated price basis.

3. Maintain only operating inventories of completed cartons. Encourage members to make offseason purchases and to provide warehousing in existing local packinghouses.

4. Plan to fabricate less than members' normal annual requirements of cartons and acquire the size of plant that will operate at capacity under such conditions.

\section{APPENDIX}

\section{UNIFORM MEMBERS' CONTRACT OF HIGHLAND CRATE COOPERATIVE}

This agreement made and executed in duplicate this day of 19 between HIGH-

LAND CRATE COOPERATIVE, a corporate cooperative Association under the laws of Florida, with principal place of business at Jacksonville, Florida, party of the first part hereinafter referred to as "ASSOCIATION", and of

party of the second part hereinafter referred to as "MEMBER",

\section{WITNESSETH that:}

WHEREAS, when this agreement is properly executed by both parties Member becomes a member-stockholder of Association and has all the rights and privileges granted by the Amended Articles of Incorporation and by-laws of Association to its member-stockholders and assumes his, her or its proportionate obligation and responsibilities in the affairs and operations of the Association; and

WHEREAS, Member is in accord with Association's methods of operation and desires to take 
advantage of the benefits of the cooperative purchasing of agricultural supplies used or usable in and in connection with the production or handling, packing and packaging of citrus fruits and in so doing, desires to assure to Association that Member will purchase from and through Association, for the period of time hereinafter mentioned, Member's requirements for such supplies as are hereinafter mentioned and set forth, now, therefore,

For and in consideration of the sum of One Dollar (\$1.00) paid to Member by Association, receipt whereof is acknowledged, and in further consideration of the expenses incurred by Association in providing means and facilities for the effectuation and carrying-out of the terms and purposes hereof, it is hereby mutually agreed as follows:

1. Member agrees that he, she or it will during the continuance hereof, purchase through and/or from Association Member's requirements of boxes, crates, or other containers handled by Association and required by Member in packing and packaging Member's citrus fruits determined as follows: on or before the 15th day of October of each and every year Member will notify Association in writing of the minimum number of such boxes, crates or containers which Member will require and purchase hereunder for his, her or its own use during the ensuing year and upon failure of Member to so notify, the Association shall use the number of such boxes, crates or containers used by Member during the previous year as the number which Member is obligated to purchase hereunder for said ensuing year.

Association agrees to use its best efforts to furnish Member his, her or its said requirements which Member has so agreed to purchase during each year that this agreement remains in force and effect; but in the event Association finds that the requirements of all its member-stockholders for such boxes, crates or containers exceeds its reasonable capacity to economically manufacture and furnish, then and in that event Association shall allocate all of the boxes, crates or containers which it is so able to furnish among all of its member-stockholder's total investment in the Association, evidenced by capital stock and equities or interest in the reserves and surplus of the Association, bears to the total amount of all such capital stock, reserves and surplus.

2. The by-laws of the Association now in existence and all the amendments thereto that may be hereafter adopted and all rules and regulations promulgated by the Board of Directors of the Association governing or in anywise related to the operations and affairs of the Association, shall be parts of this agreement and shall be binding upon the parties hereto.

3. This agreement shall be and continue in full force and effect from the date hereof for a period of ten (10) years with the privilege however, to Member to cancel and terminate the same by notice in writing delivered to the Association at any time within the ten-day period immediately prior to any annual meeting of the member-stockholders of the Association. This agreement shall be automatically terminated upon Member's ceasing to own and hold common stock of Association.

No cancellation attempted by Member shall be effectual so long as he, she or it is indebted to Association.

It is expressly agreed that the foregoing agreement relative to the terms and cancellation of this contract shall be binding upon the heirs, legal representatives, successors or assigns of Member.

4. There are no oral or other conditions, promises, covenants, representations or inducements in addition to or at variance with any of the terms hereof and this agreement represents the voluntary and clear understanding of both parties fully and completely and the terms and provisions hereof shall inure to the benefit of and be binding upon the respective heirs, legal representatives, successors or assigns of the parties hereto.

IN WITNESS WHEREOF, the said parties have duly executed this contract as of the date aforesaid.

HIGHLAND CRATE COOPERATIVE

By

President

Attest:

Secretary

Member

By

President

Attest:

Secretary 
Table A-1.-Distribution of personal interviews with fresh fruit and vegetable packers, in selected States

\begin{tabular}{|c|c|c|c|c|c|}
\hline \multirow{2}{*}{ State } & \multicolumn{5}{|c|}{ Packers interviewed that were handling- } \\
\hline & Fruits & Vegetables & Potatoes & Mixed & Total \\
\hline & ---- & ---- & Number & --- & ----- \\
\hline California & 9 & - & - & - & 9 \\
\hline Florida & 4 & 8 & - & - & 12 \\
\hline Maine & - & - & 3 & - & 3 \\
\hline Michigan & 4 & 4 & 1 & - & 9 \\
\hline New Jersey & 4 & 4 & - & - & 8 \\
\hline New York & 2 & 4 & 1 & 1 & 8 \\
\hline Pennsylvania & 3 & 3 & 1 & - & 7 \\
\hline Ohio & 4 & 4 & 1 & 2 & 11 \\
\hline Washington & 6 & - & - & - & 6 \\
\hline Total & 36 & 27 & 7 & 3 & 73 \\
\hline
\end{tabular}

Table A-2.-Quantity and value of shipments of wooden containers for fruits and vegetables by all manufacturing establishments in United States, 1963

\begin{tabular}{|c|c|c|c|}
\hline \multirow{2}{*}{ Product } & \multirow{2}{*}{ Unit } & \multicolumn{2}{|c|}{ Shipments, including interplant transfer } \\
\hline & & Quantity & Value \\
\hline & & 1,000 & $\$ 1,000$ \\
\hline \multicolumn{4}{|l|}{ Nailed or lock-corner boxes: } \\
\hline Made from lumber & Bd. ft. & 100,636 & 13,579 \\
\hline Made from veneer \& plywood & Sq. $\mathrm{ft}$. & 5,057 & 387 \\
\hline \multicolumn{4}{|l|}{ Box shook: } \\
\hline Lumber & Bd. ft. & 340,126 & 35,692 \\
\hline Veneer & Sq. $\mathrm{ft}$. & 165,205 & 7,230 \\
\hline Plywood & Sq. ft. & 104,581 & 7,082 \\
\hline Not reported & -- & --- & 871 \\
\hline \multicolumn{4}{|l|}{ Wirebound boxes and crates: } \\
\hline Made from lumber & --- & \multicolumn{2}{|c|}{ Not reported separately } \\
\hline Made from veneer \& plywood & Box & 83,888 & 28,830 \\
\hline \multicolumn{4}{|l|}{$\begin{array}{l}\text { Veneer and plywood containers, } \\
\text { other than boxes and crates: }\end{array}$} \\
\hline Pails, drums, tubs, etc. & --- & \multicolumn{2}{|c|}{ Not reported separately } \\
\hline Hampers & --- & 11,034 & 3,188 \\
\hline Stove baskets & Basket & 19,230 & 5.532 \\
\hline Short stove baskets & Basket & 19,393 & 6,522 \\
\hline Berry cups and tills & Cup \& till & 198 & 2,970 \\
\hline
\end{tabular}

Source: Lumber and Wood Products, Major Group 24. Wooden Containers and Miscellaneous Wood Products MC63(2)-24c 1963 Census of Manufactures, Bureau of the Census, U.S. Department of Commerce.

Other available reports: Three other 1963 Census of Manufactures reports contain data on shipments of paperboard, converted paper, and metal containers, but they do not specify the quantities and value used for fruit and vegetables. These are:

Paper and Allied Products, Major Group 26. Paperboard Containers and Boxes, MC63(2)-26c.

Paper and Allied Products, Major Group 26. Converted Paper \& Paperboard Products, Except Containers and Boxes. MC63(2)-26B

Fabricated Metal Products, Major Group 34. Metal Cans, Cutlery, Hand Tools and General Hardware. MC63(2)-34A. 



\section{Other Publications Available}

Cooperative Procurement of Containers for Fruit and Vegetable Processing. General Report 146, J. Warren Mather.

Supply Cooperatives. Bulletin Reprint 2. J. Warren Mather and Staff.

Cooperative Bargaining for Feed and Farm Supplies in Illinois, 1959-64. General Report 136, R. J. Mutti and L. J. McGinnis.

Collective Bargaining for Poultry Feed Prices-California. General Report 141, D. B. DeLoach and J. A. Maetzold.

Mobile Feed Milling by Cooperatives in the Northeast. General Report 99, Theodore R. Eichers and Arno J. Hangas.

Cooperative Bulk Fertilizer Blending in the Upper Midwest. General Report 122, Theodore R. Eichers.

Credit Control in Selected Retail Farm Supply Cooperatives, Area VI, New York, New Jersey, Virginia, West Virginia, North Carolina, and Georgia. General Report 70, John M. Bailey.

Improving Management of Farmer Cooperatives. General Report 120, Milton L. Manuel.

Handbook on Major Regional Cooperatives Handling Supplies, 1964 and 1965. General Report 140, J. Warren Mather.

Regional Cooperative Handling Under \$10 Million of Supplies, 1960-61. General Report 115, J. Warren Mather and Anne L. Gessner.

Statistics of Farmer Cooperatives, 1965-66. Research Report 1, Bruce L. Swanson.

Approaches and Problems in Merging Cooperatives. Information 54, Martin A. Abrahamsen and J. Warren Mather.

A copy of each of these publications may be obtained while a supply is available from-

Farmer Cooperative Service

U.S. Department of Agriculture

Washington, D.C. 20250 